\title{
RECONSTITUTING WE THE PEOPLE: FREDERICK DOUGLASS AND JÜRGEN HABERMAS IN CONVERSATION
}

Paul Gowder

\begin{abstract}
This Article draws on Black American intellectual history to offer an approach to fundamental questions of constitutional theory from the standpoint of the politically excluded.

Democratic constitutional theory is vexed by a series of well-known challenges rooted in the inability to justify law without democracy ("the countermajoritarian difficulty") and the inability to justify any particular composition of the popular demos without law ("the problem of constituent power"). Under conditions of genuine egalitarian political inclusion, a constitutional conception of popular sovereignty derived primarily from the civic republican constitutional patriotism associated with Jürgen Habermas and others can resolve these challenges by providing a conceptual basis for understanding the constitutional demos as a corporate body extending across time and capable of ongoing political legitimation.

Unfortunately, the constitutional conception cannot justify states, such as the United States, characterized by the persistent exclusion of some legitimate members of the demos from political institutions. The resolution to this problem can be found in an important tradition in Black American constitutional thought, beginning with Frederick Douglass, which represents American constitutional institutions as conditionally worthy of attachment in virtue of their latent normative potential. The correct conception of constitutional legitimacy for the United States combines Douglass's insights, and those of his intellectual heirs, with those working in the tradition which Habermas represents.
\end{abstract}

AUTHOR-I thank participants at the 2019 National People of Color Legal Scholarship Conference, at the National Conference of Constitutional Law Scholars at Arizona State University, and in seminars at the Institute for Advanced Study, Georgetown University's McDonough School of Business, McGill University's Legal Theory Workshop, and the law schools of the University of California Irvine, Northwestern University, and Boston University for very helpful feedback on drafts of this paper and (with respect to most of the above) a predecessor paper, mostly deceased, but which 
bravely evolved into the argument here. I also thank my colleagues at Iowa who very kindly participated in a workshop for this version. Finally, I thank my long-suffering and brilliant research assistants, Anne Carter and Haiyan $\mathrm{Qu}$, for, inter alia, heroic efforts to clean up the citations and convince me to avoid writing 500-word sentences, and the editorial team at the Northwestern University Law Review for careful and extraordinarily helpful edits as well as for patiently tolerating my evident Bluebook allergy.

INTRODUCTION 336

I. The Mechanical Conception and Conventional CONSTITUTIONAL THEORY

A. Digging Deeper into the Mechanical Conception...........................................343

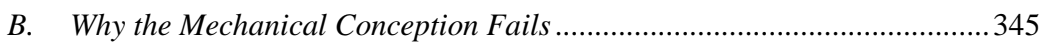

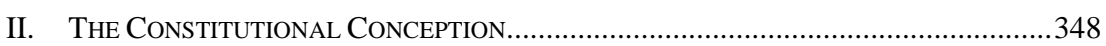

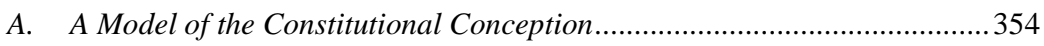

B. How the Constitutional Conception Solves the Deficiencies of the Mechanical Conception ...................................................................... 356

C. Black Exclusion and the Failure of the Constitutional Conception ..............360

III. Frederick Douglass's Constitutionalism AND CyniCAL FAITH .....................373

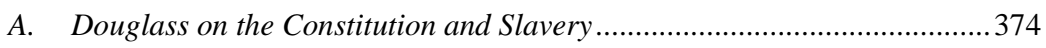

B. A Model of Black Constitutional Claimant Critique ....................................382

C. Claimant Critique and Cynical Constitutional Faith in

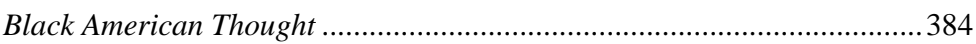

D. A Note in Defense of the Ever-Living Now .................................................405

Conclusion: Black Constitutional Patriotism: “Change the Joke AND SLIP THE YOKE" 408

\section{INTRODUCTION}

This Article reaches into the history of Black American constitutional thought to offer an account of constitutional democratic theory that can explain why we ought to treat our Constitution as meaningful, even in the face of the profoundly unjust exclusions woven deeply into its fabric. In order to do so, it operates in three methodological domains. First is "constitutional theory," the discipline within law schools focusing on the question of how governments and democratic citizens ought to respond to their constitutions: Should they be obeyed? How should they be interpreted? Second is "democratic theory," the discipline within philosophy and political science departments focusing on the question of what a government must look like in order to be described as "democratic." I contend that the core 
debates of constitutional theory depend on implicit (and false) assumptions of democratic theory. Third is "intellectual history," in particular, the history of the responses of Black American activists and scholars to the concentric series of exclusions (slavery, Jim Crow, mass incarceration) that have comprised the relationship of Black Americans to their government. ${ }^{1}$

This Article argues that the best way to resolve the perennial debates about the American Constitution's compatibility with the ideals of democracy is to borrow from two sources: (1) the civic republican constitutional patriotism associated, inter alios, with constitutional theorists Jürgen Habermas, Bruce Ackerman, Seyla Benhabib, and Frank Michelman and (2) Black American thought about the American Constitution and American democracy. From the constitutional patriots comes the idea that constitutions are normatively prior to democratic legitimacy and not-as most constitutional theory implicitly assumes - the other way around. From Frederick Douglass, Ralph Ellison, Patricia Williams, and other Black American democratic and constitutional thinkers comes the idea that there is a way to treat an unjust, exclusionary constitution as democratically legitimate in potentia and bootstrap it into legitimacy via the efforts of those who struggle for inclusion. ${ }^{2}$

The argument of this Article proceeds in three Parts.

Part I describes the conventional, if implicit, theory of popular sovereignty on which the core debates around the countermajoritarian problem in constitutional theory have revolved. This theory, which I call the "mechanical conception," supposes that popular will-formation must precede political outcomes and hence that legal acts that either resist the popular will or are enacted without its pre-approval-including judicial review - cannot be democratically legitimate. Part I then demonstrates that this theory of popular sovereignty cannot serve to describe the preconditions of democratic legitimacy.

Part II elucidates the main alternative to the conventional theory of popular sovereignty. This alternative theoretical framework, which I call the "constitutional conception," is associated with the work of scholars in the tradition of civic republican constitutional patriotism. It can explain how a

\footnotetext{
${ }^{1}$ I do not, however, claim to be offering a historical thesis, but rather to be mining the wisdom of Black constitutional thinkers throughout American history to reveal an underlying normative truth about American democracy.

${ }^{2}$ By "bootstrap it into legitimacy," I mean that Douglass and his intellectual heirs teach us that even an illegitimate Constitution can be a source of normative resources that can be used as a basis to demand the social inclusion that the Constitution promises (however falsely). If these demands are successfully satisfied, I will argue, that satisfaction can retroactively legitimate the Constitution. As I will show, this is precisely the approach to the Constitution that resolves a flaw in the arguments of the constitutional patriots.
} 
constitution like ours can both constitute and be the product of an ongoing cross-generational public identity. That identity-the We the People or demos - in turn, can make the Constitution compatible with the ideal of popular sovereignty. Unfortunately, Part II also shows that such a theory cannot justify our actual Constitution and our government in the real world because our real-world Constitution has been marred by antidemocratic exclusion, particularly, although not exclusively, of Black Americans. For that reason, there is no We the People - the American demos has never been properly constituted.

Finally, Part III draws out one response to that exclusion from a rich history of Black American constitutional and democratic commentary. It argues that even though the Constitution cannot be justified, we can find in this tradition of thought some reason to act as if it is justified, in the course of a continuing struggle to achieve the demos envisioned, in incomplete form, by the Constitution.

\section{THE MECHANICAL CONCEPTION AND CONVENTIONAL CONSTITUTIONAL THEORY}

Is the American government democratically legitimate? That is, do We, the ostensibly democratic People of the United States, have any reason to understand ourselves to be the authors of its Constitution, the judicial decisions interpreting it, and the laws enacted under its authority?

It is typically supposed that, in order to be legitimate, a democratic state must instantiate the property of "popular sovereignty," which it achieves when the people can be understood as the authors of its political outcomes. But it is notoriously difficult to justify the thought that American institutions are the product of popular authorship. There are many reasons to worry about popular authorship in the United States, but the most important are twofold:

First, the Constitution was written and ratified by white men, many of whom were slaveholders, in the eighteenth century - a population hardly representative of the contemporary citizenry. Thus, how can we say that the People alive today, who have different values and who include many who would have been excluded under the initial framing act, have authored the Constitution or political outcomes determined under it?

Second, even assuming the Constitution itself is legitimate, it is arguably interpreted illegitimately - the Supreme Court gets to decide what it means, making its decisions stick, and, in doing so, sometimes overrides the will of the people expressed through their elected representatives. How can the people be the authors of those legal outcomes when the best evidence we have for what they actually wanted is the opposite? 
These, of course, are classic problems, and constitutional theory has long struggled with them. As I contend, however, this body of theory has implicitly-and mistakenly_rested on what I term the mechanical conception of popular sovereignty. The mechanical conception is a set of suppositions about what has to be true of a governmental structure for its laws to be democratically legitimate. Put simply, the mechanical conception consists of two features of government which are required for democratic legitimacy.

First, the people must have a forward-looking mechanical power to control political outcomes (legislation, social policy, war and peace, and so forth) by operating the machinery of their political institutions, such as by voting or exercising free speech.

Second, existing political institutions and outcomes must, in a backward-looking sense, be the result of exercises of those mechanical powers. They themselves must be brought about as a result of the people operating their political machinery, as opposed to having been imposed on the people from the outside. ${ }^{3}$

To see that compliance with the mechanical conception is a central concern of constitutional theory, consider how it has been invoked to underpin the central problem of constitutional theory-the countermajoritarian problem.

In the words of Professor Barry Friedman, "to the extent that democracy entails responsiveness to popular will, how to explain a branch of government whose members are unaccountable to the people, yet have the power to overturn popular decisions?" 4 Professor Steven Calabresi sees the countermajoritarian problem as about "disempower[ing] current majorities from ruling either in the name of a majority of white male property owners that died out more than 150 years ago or because a current majority of nine unelected elite lawyers do not agree with the popular will." ${ }^{5}$ Alexander Bickel argues that "when the Supreme Court declares unconstitutional a legislative act or the action of an elected executive, it thwarts the will of representatives of the actual people of the here and now."6

\footnotetext{
3 See, e.g., Lars Vinx, The Incoherence of Strong Popular Sovereignty, 11 INT'L J. ConST. L. 101, 101 (2013) (criticizing the German Federal Constitutional Court for endorsing a conception of popular sovereignty that requires the constitution to be a product of preexisting popular will).

${ }^{4}$ Barry Friedman, The History of the Countermajoritarian Difficulty, Part One: The Road to Judicial Supremacy, 73 N.Y.U. L. REV. 333, 335 (1998).

5 Steven G. Calabresi, Textualism and the Countermajoritarian Difficulty, 66 GEO. WASH. L. REV. 1373, 1385 (1998).

${ }^{6}$ Alexander M. Bickel, The Least Dangerous Branch: The Supreme Court at THE Bar of Politics 16-17 (2d ed. 1986).
} 
Elsewhere, I have described this as the "thwarting" complaint and traced its history to Classical Athens, where it was first raised to resist an attempt to prevent the Assembly from summarily executing some generals. ${ }^{7}$ Perhaps its most canonical American expression came in Lincoln's First Inaugural Address, which, implicitly referring to Dred Scott v. Sandford, directly connects the judicial thwarting of electoral will to the failure of popular sovereignty:

[I]f the policy of the Government upon vital questions affecting the whole people is to be irrevocably fixed by decisions of the Supreme Court, the instant they are made in ordinary litigation between parties in personal actions the people will have ceased to be their own rulers, having to that extent practically resigned their Government into the hands of that eminent tribunal. ${ }^{8}$

These canonical descriptions of the countermajoritarian problem rest on the supposition that popular sovereignty consists in the people's ability to use the electoral process to control political outcomes, such that the exercise of judicial power to frustrate that control undermines the democratic legitimacy of the American government.

Major efforts to resolve the countermajoritarian problem have also implicitly assumed the mechanical conception of popular sovereignty. For example, John Hart Ely's theory of representation-reinforcement judicial review addresses the tension between constitutional judicial review and the mechanical conception by positing that the appropriate function of judicial review is to support the efficacy of democratic politics and hence the control of the people over their political machinery, for example, by protecting their rights to voting and free speech. ${ }^{9}$

Similarly, the theory of popular constitutionalism, associated with scholars such as Larry Kramer, supposes that the people can also exercise control over constitutional review and hence convert it from a hinderance of their sovereign machinery to an exercise of it. ${ }^{10}$

Yet those efforts to reconcile constitutionalism with popular sovereignty on a mechanical conception have not been wholly successful. Both are vexed with a problem of fundamental indeterminacy, rooted in the fact that the people can conceivably instantiate their will in multiple ways.

\footnotetext{
7 Paul Gowder, The Countermajoritarian Complaint, 23 TRANSNAT'L L. \& CONTEMP. PROBS. 7, 10 11 (2014).

${ }^{8}$ First Inaugural Address of Abraham Lincoln: Monday, Mar. 4, 1861, Avalon ProJ. http://avalon.law.yale.edu/19th_century/lincoln1.asp [https://perma.cc/5NF3-XT5Q].

9 See generally John Hart Ely, Democracy and Distrust: A Theory of Judicial Review (1980) (developing the general theory of representation-reinforcement).

10 See generally Larry D. Kramer, Popular Constitutionalism, Circa 2004, 92 CALIF. L. REV. 959 (2004) (reviewing popular constitutionalist literature).
} 
Thus, the democratic legitimacy of constitutional judicial decision-making cannot be established by articulating an account of how those decisions support democratic processes because the judicial outcomes that may support democratic processes are underdetermined. For example, there are genuine and serious arguments on both sides of the campaign finance debate about the extent to which cases such as Buckley v. Valeo ${ }^{11}$ and Citizens United v. FEC $C^{12}$ promote popular control over political outcomes (i.e., by providing more opportunities for political speech) or undermine them (by permitting the wealthy to dominate elections). The same point more generally: any question of what legal rules best protect democratic processes is itself a question that is potentially subject to democratic debate - debate which representation reinforcement-style judicial review cuts off. ${ }^{13}$ For another example, Americans deeply disagree about the appropriateness of laws regulating voting, such as voter ID legislation, as well as the degree of deference to be paid to states enacting such laws; these disagreements have leaked into Supreme Court rulings in the form of decisions like Shelby County v. Holder. ${ }^{14}$ The Supreme Court taking a position on those disagreements cannot be justified simply by pointing to the necessity of coming to some decision for democracy to move forward, for it is often denied that the Court has come to the right decision or that it is its place to make the decision at all.

Moreover, representation reinforcement theory cannot resolve the core problem of generational difference: They the People of 1788 are not We the People of 2019, and by what right do the 1788 people rule us today? ${ }^{15}$ This

\footnotetext{
11424 U.S. 1, 19-23 (1976) (holding that political campaign expenditures are protected by the First Amendment).

12558 U.S. 310, 318-19 (2010) (striking restrictions on independent campaign expenditures by corporations and labor unions).

13 Even declining to decide such questions, as with the Supreme Court's 2018 decision to duck the question of partisan gerrymandering by resolving Gill $v$. Whitford on a standing issue, amounts to making a decision - in that case, permitting one partisan group to (allegedly) cut off the effective access to the democratic process of another. 138 S. Ct. 1916, 1929 (2018). The same point applies to the Court's 2019 decision to treat partisan gerrymandering as a nonjusticiable political question in Rucho v. Common Cause, 139 S. Ct. 2484, 2508 (2019).

14133 S. Ct. 2612 (2013) (striking down the formula for determining which states are subject to Voting Rights Act preclearance under a theory of equal state sovereignty).

15 See, e.g., Michael J. Klarman, Antifidelity, 70 S. CAL. L. REV. 381, 381 (1997) ("Why would one think, presumptively, that Framers who lived two hundred years ago, inhabited a radically different world, and possessed radically different ideas would have anything useful to say about how we should govern ourselves today?"). That this has been a worry about the American Constitution since the Founding generation is evidenced by a famous letter from Thomas Jefferson to James Madison of September 6, 1789. 15 THE PAPERS OF THOMAS JEFFERSON: 27 MARCH 1789 TO 30 NOVEMBER 1789, at 392-98 (Julian P. Boyd \& William H. Gaines, Jr. eds., 1958) (arguing that constitution-makers have no right to bind future generations); see also Todd E. Pettys, Popular Constitutionalism and Relaxing the Dead Hand:
} 
generational difference can undermine the basic structure of democratic selfrule. For example, the Electoral College and the malapportionment of the Senate are controversial and were established in a very different society from the one in which we live-we have no reason to believe that the social, political, and economic concerns that might have animated the Framers in creating them persist today. Yet they control how we make our democratic decisions, including the democratic decision to keep or abandon those institutions.

The theory of popular constitutionalism suffers from the inverse problem. In order for the people to make decisions about what their law is, they need to have some law in the first place. This is an ancient problem, known to political theorists as the problem of constituent power: the identity of a democratic people (its boundaries and the institutions through which it forms and carries out its will) necessarily has to precede its democratic acts - as a corporate entity, a demos cannot form a will or act until some legal act has brought it into existence. But then how do we democratically legitimate that first act? ${ }^{16}$ But the problem of constituent power is not merely limited to the question of what legitimates the first act of lawmaking in a democratic state; I submit that it also persists into its constitutional operations. We cannot identify any particular popular act as a legitimate act of constitutional interpretation without some preexisting body of constitutional law which sets the criteria for such legitimacy, and which cannot itself be interpreted by any such popular act on pain of circularity.

It seems to me that these difficulties, and the more general difficulty of reconciling constitutional law and the mechanical conception of popular sovereignty, highlight a tension in the heart of that conception. We cannot imagine a democratic people without law, for law is what both constitutes a

Can the People Be Trusted?, 86 WASH U. L. REV. 313, 326 (2008) (quoting similar arguments from Thomas Paine and Noah Webster) (citations omitted).

16 This is a problem that has vexed democratic theorists for a very long time. See CHRISTOPHER Meckstroth, The Struggle for Democracy: Paradoxes of Progress and the Politics of CHANGE 15-20 (2015) (providing a very helpful review of the recent literature); see also Bonnie Honig, Between Decision and Deliberation: Political Paradox in Democratic Theory, 101 Am. PoL. SCI. Rev. 1, 5 (2007) (interpreting philosophy of Rousseau in context of a "paradox of politics" that there can be no general will or popular perspective from which to issue the laws necessary to create that perspective). For a concise (albeit skeptical) description of the problem of constituent power and its role in legal theory, see David Dyzenhaus, Constitutionalism in an Old Key: Legality and Constituent Power, 1 GloBAL CONSTITUTIONALISM 229, 233-34 (2012). Incidentally, Dyzenhaus makes an argument quite congenial to the articulation of the constitutional conception in Part II of this Article, defending the idea of a Habermasian self-constituting rule of law as an alternative to classical ideas of constituent power, on the condition that such a rule of law provides its people with "stake," "independence," and "part," that is, genuinely includes them in the demos. Id. at 255-56. 
demos and allows it to operate; ${ }^{17}$ at the same time, the mechanical conception asks us to conceive of a demos unbounded by law, for legal constraints on the demos thereby undermine its control over political outcomes.

However, arguing against these efforts to reconcile the mechanical conception and constitutional law is not the mission of this Part. Instead, I argue that the mechanical conception fails on its own terms. Accordingly, we do not need to engage with the conventional arguments around the countermajoritarian problem: those arguments start around a misconstrual of what democracy is..$^{18} \mathrm{I}$ shall proceed to this argument immediately.

\section{A. Digging Deeper into the Mechanical Conception}

My description of the mechanical conception is not meant to identify any particular scholar's view. Instead, I claim that it is a latent set of assumptions that seem to run underneath much of mainline democratic and constitutional theory; in other words, it is a general characterization of a category of views about popular sovereignty which has some popularity. As I intend to argue against it, it is expected that this model of the conception will have some intuitive grip on at least a substantial minority of readers (otherwise, I may be in danger of confronting a straw-person).

This conception, as I interpret the broad presuppositions of American democratic thought, is the premise that the way in which the people rule is that they intentionally and reliably exercise causal power over the ordinary political decisions of their states, typically through a kind of mechanical control over those decisions via operating their political institutions. Put differently, should a sufficient number of people choose to implement some political outcome (lower taxes, the legalization of marijuana, the initiation of a war), they have the power to bring that outcome into being via their political institutions. For example, they may pass an initiative or referendum to legalize marijuana, or they may elect representatives who share their views on lower taxes.

Examples of the mechanical conception in democratic theory as produced by political theorists abound. Consider Robert Dahl's suggestion that majority preferences are to be tracked "whenever policy alternatives are perceived to exist," 19 or Philip Pettit's supposition that a democracy must allow citizens control over the discretionary decisions that the state takes in

\footnotetext{
17 See generally Paul Gowder, Response, The Rule of Law Against Sovereign Immunity in a Democratic State, 93 TEX. L. REV. 246, 247, 250-52 (2015) (arguing that the rule of law is conceptually prior to democratic self-rule).

18 I.e., because the mechanical conception fails, for reasons I shall describe, it cannot be a correct account of democracy.

19 Robert A. Dahl, A Preface to Democratic Theory 37 (Expanded ed. 2006).
} 
imposing rules on them. ${ }^{20}$ In both cases, the idea seems to be that the stuff of popular authorship, and hence sovereignty, is mass control, via political institutions, of day-to-day political outcomes. ${ }^{21}$

I am not the first to identify a latent mechanical conception in the existing literature - the idea has sufficient popularity that some democratic theorists have been at pains to deny that it exists. Recently, Andrew Sabl has argued that empirical political scientists have frequently erred in supposing that democratic theory properly understood includes some criterion of "responsiveness" according to which legitimacy demands that citizens can successfully bring about political outcomes in accordance with their preferences. $^{22}$ "Responsiveness" is essentially the same thing as the mechanical conception; however, contra Sabl, many important contributions to democratic theory (in addition to the examples cited in the previous paragraph) implicitly include a responsiveness criterion similar to that assumed by constitutional theorists. ${ }^{23}$ However, nothing in this Article rests

20 Philip Pettit, On the People's Terms: A Republican Theory and Model of Democracy 166 (2012)

${ }^{21}$ By "political outcomes," I mean, roughly, ordinary laws, policies, and other discrete exercises of the state's monopoly over violence. The mechanical conception need not be inconsistent with representative government-you can have a version of the mechanical conception which supposes that citizens operate representative machinery to control their political outcomes, for example, by electing representatives who promise to repeal the prohibition on marijuana and unelecting them if they fail to do so. Nor need the mechanical conception be inconsistent with a dialogic relationship between citizens and representatives - it is possible to have a mechanical conception that supposes, for example, that it is permissible for the citizens to vote for a marijuana legalization candidate, for that candidate to learn new things about the implications of legalization once in office, and for that candidate to decline to repeal the prohibition but manage to stay in office by convincing the voters that this was the right decision after all.

22 Andrew Sabl, The Two Cultures of Democratic Theory: Responsiveness, Democratic Quality, and the Empirical-Normative Divide, 13 PERSP. ON POL. 345 (2015). Versions of this debate have been going on for decades, and the pattern is familiar: some social scientist or cynical democratic theorist attempts to debunk democratic theory, and less cynical democratic theorists respond by saying, in essence, "that's not what we were talking about." See, e.g., William H. Riker, Liberalism Against Populism: A CONFRONTATION BETWEEN THE THEORY OF DEMOCRACY AND THE THEORY OF SOCIAL CHOICE (1982) (arguing that problems of collective preference formation make the aspirations of democratic theory in the tradition of Rousseau impossible to achieve); Carole Pateman, Social Choice or Democracy? A Comment on Coleman and Ferejohn, 97 ETHICS 39 (1986) (arguing that social choice theorists such as Riker have mischaracterized Rousseau's democratic theory); Diana C. Mutz, Is Deliberative Democracy a Falsifiable Theory?, 11 ANN. REV. POL. SCI. 521 (2008) (identifying empirical challenges for political philosophers who claim that democratic deliberation is possible or socially beneficial); Dennis F. Thompson, Deliberative Democratic Theory and Empirical Political Science, 11 ANN. REV. PoL. SCI. 497 (2008) (criticizing existing literature in deliberative democracy for inadequate engagement between theoretical and empirical research).

${ }^{23}$ Contra Sabl, supra note 22. Sabl observes that some deliberative democrats focus on the shaping of preferences by deliberative institutions. Id. at 348 . However, many deliberative democrats also tend to suppose that those shaped preferences then exercise power over political outcomes via the operation of political institutions. Deliberative democratic citizens are deliberating in order to come to a decision, and doing so in order to make that decision, that is, to carry it out in the public sphere. See, for example, the 
on the contention that democratic theorists have fallen into the mechanical conception - it is enough for my argument that constitutional theorists have done so.

\section{B. Why the Mechanical Conception Fails}

Unfortunately, the mechanical conception is vexed by two distinct problems making it difficult - perhaps impossibly so - to reliably satisfy. I suggest that, for this reason, we ought to abandon the mechanical conception wholly independent of its incompatibility with constitutional theory. That is, it is a problem for American constitutional theory that judicial review does not really seem to be compatible with the notion of the people exercising a forward-looking and a backward-looking mechanical power over political outcomes. We can resolve that problem either by abandoning judicial review or by abandoning the mechanical conception of popular sovereignty. And I suggest that the mechanical conception is so unrealistic - real states are so unlikely to satisfy it - that we ought to just let it go and replace it with a framework for democratic theory that puts the constitutional horse before the democratic cart (the subject of Part II of this Article).

The first fatal problem for the mechanical conception is the problem of corrupt origins. There is always a potential paradox associated with democratic forms of organization, in view of the worry that the demos must exist as a corporate entity before it can legitimate anything, including the legal act bringing it into existence. ${ }^{24}$ However, even supposing that we can

terms in which Freeman describes deliberative democracy — as a decision-making procedure to actually carry out mass political power. Samuel Freeman, Deliberative Democracy: A Sympathetic Comment, 29 PHIL. \& PUB. AfF. 371, 372, 382 (2000) (describing deliberative democracy as a procedure to inform citizens' votes, in the context of democracy in general as a process of lawmaking). The kind of deliberative democratic view advanced by James S. Fishkin et al., Deliberative Polling and Public Consultation, 53 PARLIAMENTARY AFF. 657 (2000), has actually been criticized by other democratic theorists for recommending participatory institutions that fail to translate their recommendations into political outcomes. See, e.g., Carole Pateman, Participatory Democracy Revisited, 10 PERSP. ON POL. 7, 9, 14 (2012) ("At worst, [citizen] juries are little more than focus groups, or they become useful legitimating devices for an already-decided policy," and that "[m]any other examples called "participatory budgeting' are merely consultative or provide information."). The mechanical conception also often creeps into democratic theory through accounts of representation, which suppose that the people have the power to hold their representatives accountable for carrying out their political ends or influencing political outcomes. See, e.g., Nadia Urbinati \& Mark E. Warren, The Concept of Representation in Contemporary Democratic Theory, 11 ANN. REV. POL. SCI. 387, 389, 395-96 (2008). Sometimes, the mechanical conception enters democratic theory through the idea of "political equality," which is often supposed to mean that each citizen has an equal chance of determining political outcomes - this is why Jane Mansbridge asserts that if a democracy cannot follow the will of a majority in cases of political conflict, it "can no longer be said to have weighed the interests of all citizens equally." Jane Mansbridge, Using Power/Fighting Power, 1 Constellations 53, 53 (1994).

24 See MeCKSTROTH, supra note 16, at 15-20 and accompanying text; see Honig, supra note 16, at 5 . 
come up with an account of constituent power that avoids this paradox, the unfortunate fact of the matter is that every real-world democracy has come into being in ways that are unlikely to be legitimate even in principle. Philosopher David Hume, of course, said this best in his essay Of the Original Contract:

Almost all the governments which exist at present, or of which there remains any record in story, have been founded originally either on usurpation or conquest or both, without any presence of a fair consent or voluntary subjection of the people..$^{25}$

At their founding moments, the fundamental laws of democracies have tended to be imposed by narrow parties, often composed of social elites, rather than by genuine representatives of the political community as a whole. Some of them have been imposed by foreign hegemons and colonial powers or have come into being as a result of tainted compromises between a nascent demos and its previous dictator. ${ }^{26}$ Even in those polities that have managed to take effective control of their own fundamental laws, those processes have still often been tainted by influence-peddling, meddling, and corruption. Even if it is possible for a people, properly understood, to give itself its own fundamental law, it is doubtful that it has ever happened. ${ }^{27}$

25 David Hume, Of the Original Contract (1748), reprinted in Hume's Moral AND Political Philosophy 356, 360 (Henry D. Aiken ed., Hafner Press 1948).

${ }^{26}$ See, e.g., Claudia Heiss, Legitimacy Crisis and the Constitutional Problem in Chile: A Legacy of Authoritarianism, 24 CONSTELLATIONS 470 (2017) (arguing that Chile still suffers under a constitution tainted by political necessities arising from the country's transition out of authoritarianism); Douglas Lemke \& Jeff Carter, Birth Legacies, State Making, and War, 78 J. POL. 497 (2016) (describing methods of origin of states and long-term consequences, including "derelict decolonization," the abrupt departure of a colonial power, leaving a nascent state without political institutions). On governments imposed by foreign hegemons, even ostensibly democratic ones, U.S. state-building efforts in Iraq may serve as an example.

27 One objection to this point might be that a people can be self-ruling even if its fundamental law has been given by another, to the extent that lawgiving activity provides a foundation within which they can exercise an authorial power. For example, I wrote this Article in a word-processing program. I did not personally write the source code for the word processing program, but I am nonetheless the author of the things I write with it. I do not need to be the author of the tools that I use to write in order to be the author of the things I write. The same might be said for political outcomes. (I thank Mihailis Diamantis for raising this point and for the word processor example.)

To this objection, I reply that the extent to which my lack of authorship (and hence control) over my tools undermines my capacity to become the author of the things I make with the tools depends on the extent to which the tools available to me constrain that which I may author with them. It happens to be the case that word processors exercise a fairly light constraint on the things I can author with them-I can write pretty much anything with them that is expressible in the languages I speak. Moreover, I have a wide choice in word processors. The same is not obviously true for citizens who are born into an entrenched constitution that limits their political outcomes, either in virtue of the way it structures their democratic process (like the Electoral College) or the side constraints it imposes on it (like the Bill of Rights). Rather than a word processor, the appropriate writing tool analogy for a very constraining 
Second is the broken machinery problem. It turns out to be almost impossible for democratic publics to actually take control of day-to-day political outcomes. This is true both for formal reasons and for empirical reasons.

In the first category, consider that social choice theorists from Professor Kenneth Arrow onward have shown that under many conditions, there is no way to translate individual wills into a collective policy that consistently reflects those wills. ${ }^{28}$ The literature contains a variety of ways to cope with social choice problems, including sacrificing some of the fairly modest Arrovian formal criteria, according to which it is supposed that individual wills cause collective policies, or devising institutions which we imagine will lead citizens to develop "single-peaked" preferences which can dodge the dangers of social choice theory. ${ }^{29}$ However, it is fair to say that none have been fully satisfactory and that social choice results continue to trouble all attempts to causally attribute collective decisions to aggregate individual wills in a coherent fashion.

In the second category, consider the burgeoning literature on citizens' inabilities to competently form individual political wills or figure out what kinds of action to take in order to translate those wills into outcomes. Some scholars suggest that citizens of democratic states suffer from widespread failures of means-end rationality. They are unable to make the actions their state takes track the ends they aim to achieve because they lack skills, such as understanding what policies will lead to what consequences, and even what votes (e.g., for representatives) will lead to what policies. ${ }^{30}$ Others

constitution might be Orwell's Newspeak, as a constrained language that undermines the agentic capacity of its users.

28 E.g., Christian List \& Phillip Pettit, Group Agency: The Possibility, Design, And Status OF CORPORATE AGENTS ch. 2 (2011). Broadly speaking, scholarship in this tradition has argued, starting with Arrow's Impossibility Theorem, that there are formal mathematical inconsistencies among relatively modest sets of desiderata for any method of aggregating the preferences of individuals into a collective decision (like an election). See generally Christian List, Social Choice Theory, in STANFORD ENCYCLOPEDIA OF PHILOSOPHY (Edward N. Zalta ed., Winter 2013), https://plato.stanford.edu/ archives/win2013/entries/social-choice/\#ArrThe [https://perma.cc/58NA-NUG5] (explaining Arrow's impossibility theorem).

29 See, e.g., John S. Dryzek \& Christian List, Social Choice Theory and Deliberative Democracy: A Reconciliation, 33 BRIT. J. POL. SCI. 1, 14-18 (2003) (arguing that deliberation narrows the scope of democratic decisions in a fashion conducive, for mathematical reasons, to the coherence of those decisions).

30 Perhaps the most over-the-top example: Christopher Achen and Larry Bartels offer some evidence in support of the claim that shark attacks caused meaningful damage to Woodrow Wilson's share of the 1916 New Jersey vote and argue that this is not because, e.g., voters were dissatisfied with Wilson's response to the attacks, but simply because they were lashing out at the nearest available target to retaliate for their suffering. CHRISTOPHER H. ACHEN \& LARRY M. BARTELS, DEMOCRACY FOR REALISTS: WHY Elections Do Not Produce ResPonsive Government 120-28 (2016). This result has lately been subject to some controversy. Anthony Fowler \& Andrew B. Hall, Do Shark Attacks Influence Presidential 
identify similarly ineffective political behavior but characterize it as a success of means-end rationality because aggregate decision-making is characterized by "rational ignorance": the more people involved in a decision, the less incentive any individual person has to take the trouble to decide well - or even to decide at all, at which point rational ignorance becomes rational apathy. ${ }^{31}$ Again, there has been an important countertrend in various theories of what might be called, following Professor Josiah Ober, "democratic knowledge," ${ }_{2}$ but it is as yet far from clear that democratic knowledge can triumph over the skeptics. ${ }^{33}$

Such an undifferentiated record of practical failure gives us reason to believe that success is beyond our reach. At the very least, the mechanical conception seems unlikely to give us much reason for hope about democracy in the real world. This might not be a reason to reject the mechanical conception. Perhaps democracy is just some impossible dream, although for methodological reasons which I have discussed elsewhere, I think we ought to look for a conception of democracy that can do something to help us understand the virtues, however imperfect, of actual states for which we have used the label. ${ }^{34}$ At any rate, the impossibility of satisfying the mechanical conception certainly gives us some reason to turn to the alternatives, which I shall do immediately.

\section{The CONSTITUTIONAL CONCEPTION}

In this Part, I will sketch an alternative to the mechanical conception. I will call it the "constitutional conception," and it represents a generalization of the kind of theory of popular sovereignty described inter alios by

Elections? Reassessing a Prominent Finding on Voter Competence, 80 J. POL. 1423 (2018) (critiquing Achen and Bartels as described).

31 See, e.g., Jason Brennan, Against Democracy (2016) (arguing that democracy is morally objectionable, in part because of rational ignorance); ILYA SOMIN, DEMOCRACY AND POLITICAL IGNORANCE: WHY SMALLER GOVERNMENT IS SMARTER (2013) (similar). Just for context, one recent estimate of the average voter's chance of determining a U.S. presidential election was one in sixty million. Andrew Gelman et al., What Is the Probability Your Vote Will Make a Difference?, 50 ECON. INQUIRY 321, 323-24 (2012).

32 See generally JOSIAH OBER, DEMOCRACY AND KNOWLEDGE: INNOVATION AND LEARNING IN Classical ATHENS (2008) (analyzing Ancient Athenian political structure as a set of effective democratic knowledge-aggregation institutions); HÉLÈnE LANDEMORE, DEMOCRATIC REASON: Politics, Collective InTELligenCE, AND THE RUle OF THE MANY (2013) (arguing that "wisdom of crowds" enables democracies to make good decisions notwithstanding cognitive/knowledge failures of individual citizens).

${ }^{33}$ See generally Samuel Bagg, The Power of the Multitude: Answering Epistemic Challenges to Democracy, 112 AM. POL. SCI. REV. 891, 892-94 (2018) (describing the current state of the debate).

34 Paul Gowder, Institutional Values, or How to Say What Democracy Is, 30 Sw. PHIL. Rev. 235, 240-41 (2014) (arguing that "democracy" requires appeal to real-world observations of states to characterize its conceptual structure). 
constitutional theorists Jürgen Habermas, ${ }^{35}$ Bruce Ackerman, ${ }^{36}$ Seyla Benhabib, ${ }^{37}$ Frank Michelman, ${ }^{38}$ Robert Post,,${ }^{39}$ and Reva Siegel. ${ }^{40}$ This set of related theories draws elements from civic republicanism, from the presumptive ambitions of constitutional founders, from the experiences of citizens in constitutional republics, and from ambitious claims about the identity of popular agents extending over time. On such theories, the mechanical conception of popular sovereignty is made, at least partly, to run in reverse, insofar as at least some political outcomes lead the popular willformation that legitimates them.

The constitutional conception is, at heart, an account of Us the People according to which 1788 Americans and 2019 Americans represent a continuous demos with an ongoing political identity. Professor Ackerman, for example, supposes that the generations are in conversation with one another through moments of constitutional authorship. ${ }^{41}$ Professor Habermas supposes that the generations represent a continuous process of learning and discursive legitimation through democratic institutions. ${ }^{42}$ These theories ostensibly allow us to understand popular sovereignty as dynamic, not static, and understand ourselves as co-authors with prior generations of the Constitution.

These ideas have been most helpfully developed in the course of a series of conversations from the late 1990s and early 2000s about civic republicanism, Professor Habermas's discourse theory, and, most interestingly, a collection of ideas known as "constitutional patriotism." I will describe the core of these conversations between Professors Habermas, Michelman, and Ackerman in a few paragraphs.

\footnotetext{
35 See, e.g., Jürgen Habermas, Human Rights and Popular Sovereignty: The Liberal and Republican Versions, 7 RATIO JURIS. 1 (1994).

36 See, e.g., 1 Bruce ACKerman, We the PeOPle: Foundations (1991).

37 See, e.g., SEYla BENHABIB, ANOTHER COSMOPOLITANISM (Robert Post ed., 2006).

38 See, e.g., Frank I. Michelman, Brennan And Democracy (1999); Frank I. Michelman, Constitutional Authorship, in CONSTITUTIONALISM: PHILOSOPHICAL FOUNDATIONS 64 (Larry Alexander ed., 1998); Frank I. Michelman, Morality, Identity, and 'Constitutional Patriotism', 14 RATIO JURIS. 253 (2001).

39 See, e.g., Robert Post \& Reva Siegel, Roe Rage: Democratic Constitutionalism and Backlash, 42 HARV. C.R.-C.L. L. REV. 373 (2007).

${ }^{40} I d$.

41 Bruce Ackerman, A Generation of Betrayal?, 65 FordHAM L. REV. 1519, 1519-20 (1997) (describing role of generations in constitutional meaning-formation).

42 Jürgen Habermas, Constitutional Democracy: A Paradoxical Union of Contradictory Principles?, 29 POL. THEORY 766, 774-75 (2001) (responding to the problem of constituent power by understanding a constitution as "a tradition-building project with a clearly marked beginning in time" that constitutes a "learning process" based, in turn, on the "shared practice" of making something out of their constitution).
} 
Constitutional patriotism, as described by Professor Jan-Werner Müller, is as a political ambition rooted in a postwar Germany where the constitution had originally been "imposed from the outside" but grew to become "the most respected public institution of the country." Müller's account, it became the basis for a theory of patriotism that could be acceptable to German intellectuals, such as Professor Habermas, who were obliged by the history of National Socialism to reject any kind of ethnonational identification for the German people, while still retaining enough of a collective identity to take responsibility for the crimes of that history. ${ }^{44}$

Constitutional patriotism is a kind of multi-headed beast. As Professor Müller recounted, it is a theory of post-nationalist civic attachment, especially in the German context, and it has been put to service in debates about the European Union and the possibility of transnational attachment. ${ }^{45}$ However, it has also served as a theory of popular sovereignty, particularly when it has been transposed to the American literature. ${ }^{46}$

As theory of popular sovereignty, constitutional patriotism can be seen as a partial answer to one of its fundamental problems, to wit: popular sovereignty appears to be necessarily paradoxical. Professor Bonnie Honig explains this problem in terms of Rousseau, suggesting that democratic legitimacy cannot proceed from a "people" with a "general will" at all. This is because the "people" as currently constituted can never fully satisfy the normative demands of democratic theory, such as an appropriate orientation toward the common good. ${ }^{47}$ More abstractly, it appears in the form of an answer to the question that the problem of constituent power poses: How can

43 JAN-WeRnER MÜLLER, CONSTITUTIONAL PATRIOTISM 21 (2007). Professor David Law gives an account of Japan's constitution that not only problematizes the notion of an imposed constitution but might serve as a key empirical illustration of some key prerequisites of real-world constitutional patriotism: a constitution imposed by military victory on political elites, but adapted through democratic and legal processes to fit the people as well as commanding wide mass support. David S. Law, The Myth of the Imposed Constitution, in Social AND Political Foundations of Constitutions 239 (Denis J. Galligan \& Mila Versteeg eds., 2013).

${ }^{44} I d$. It is striking to compare this history to that of the United States. The Reconstruction Amendments were also imposed on the South by a military victor, but the South never developed a kind of constitutional patriotism, I submit, because it was never forced to reject the ethnic nationalism on which its antebellum law was founded. Hence, Jim Crow.

45 See, e.g., Justine Lacroix, For a European Constitutional Patriotism, 50 PoL. STUDS. 944 (2002) (arguing that constitutional patriotism has the resources to answer nationalist objections to European integration).

${ }^{46}$ I'm also playing a little bit fast and loose with boundaries of different theoretical categories here. The conversation between Professors Habermas and Michelman, on which I primarily draw, also sometimes gets expressed in terms of republicanism and other such categories; only part of Professor Habermas's general discourse-theoretic theory of legal legitimation would properly be labelled "constitutional patriotism." However, for terminological convenience, I'm running it all together under the single label.

47 Honig, supra note 16, at 122-23. 
a demos democratically legitimate the act of constitution-making which makes the demos itself?

"Retroactively," the constitutional patriot replies. The essence of the idea is that we can understand citizens and constitutional founders as coauthors of the constitutional foundations of their government to the extent that they are attached to those foundations in the right way and participate in the development of the universalistic (as opposed to particularistic, nationalistic) values underlying those foundations. ${ }^{48}$ Because the alreadyconstituted current generation of the demos participates in the act of constitution-making with the founding generation, the institutional capacity of today's people to generate legitimate decisions can, via that crossgenerational shared enterprise, legitimate the founding acts as well.

Professor Ackerman's theory is perhaps the most explicitly crossgenerational version of what I am calling the constitutional conception. As previously mentioned, Ackerman imagines American constitutionalism as an intergenerational conversation among a people with a continuous political identity. ${ }^{49}$ If we accept this notion, it seems to move us toward rejecting at least some objections to the American Constitution based on generational difference. It's not that some dead people are ruling us, the people of today, via some entrenched law and countermajoritarian courts; rather, We the cross-generational People are continuously ruling ourselves, using the countermajoritarian courts to manipulate both the temporal reach and the fixity of our decisions. ${ }^{50}$

Yet, for reasons expressed most clearly by Professor Frank Michelman, Professor Ackerman's theory of cross-generational legitimacy requires a

\footnotetext{
48 I draw this description largely from Professor Honig's interpretation (and critique) of the idea. Bonnie Honig, Dead Rights, Live Futures: A Reply to Habermas 's “Constitutional Democracy”, 29 POL. THEORY 792-805 (2001).

49 See ACKERMAN, supra note 36 and accompanying text; see also Ackerman, supra note 41 and accompanying text.

50 Note, however, that this cannot resolve all versions of the countermajoritarian objection to judicial review. It resolves versions of the objection where the problem arises from the fact that the democratic will of the people today is thwarted by unelected judges applying entrenched law which is itself not legitimated by that same democratic will — an objection which it resolves by declaring that the law being applied is indeed itself legitimated by the same democratic will, as today's majority and the constitutional framers are taken to represent the same underlying democratic agent. But it does not necessarily resolve objections, such as Professor Waldron's, which focus on the point that the people may disagree about what a constitution means and that resolution of that decision by judges, rather than majorities, is itself undemocratic, even if the constitution itself is democratically legitimate. Jeremy Waldron, The Core of the Case Against Judicial Review, 115 YALE L.J. 1346, 1393-94 (2006). However, it does make the problem Professor Waldron raises somewhat less daunting, since we might be able to imagine more-orless popular constitutionalist techniques to incorporate majority views into the process of judicial review, and the argument of this Article suggests that those techniques can be legitimate in virtue of the Constitution's own legitimacy.
} 
fundamental core of commitment to shared cross-generational values..$^{51}$ The worry (perhaps Professor Michelman's, definitely mine) is that for a continuous political identity to make sense across generations with very different circumstances and perhaps even different short-term goals and basic presuppositions of political life, some form of shared intergenerational agency must be found, in terms of some shared goals. That is, suppose I ask the question, "Why should what Hamilton and Madison and the people who lived at that time thought about political organization bear at all on how we organize our lives today?" The answer, "Because we're participating in a shared enterprise with them," seems implausible unless we can point to some shared high-level goals, and some point to the enterprise beyond just the coincidental fact that we happen to occupy the same geographic territory and happen to have started off living under their rules. ${ }^{52}$

It is this shared identity in terms of political right as expressed in constitutional ideals that Professor Habermas's version of constitutional patriotism is supposed to provide. As I read Habermas's argument, a democratic constitution and the historical practices that have fleshed it out supply a normative foundation that can connect past and future generations. ${ }^{53}$ Every generation has shaped the practices which fill out a country's constitutional outline; when we interpret that constitution we also interpret those practices and that history. It is this practice of joint interpretation in terms of a continuous set of ideas that themselves putatively represent some kind of distinctive value and identity claims (we're the kind of people who value "free speech" a lot more than other democratic societies, for example) which licenses us to attribute a shared scheme of value, and hence a shared identity, to We the People across generations. ${ }^{54}$

51 Michelman, Constitutional Authorship, supra note 38, at 76-81.

52 It seems to me that the notion of a shared value underneath constitutional institutions is a core feature of liberal constitutional democracies. Humans tend to want some reason beyond strategic expedience for attachment to their states. In view of the liberal character of the states with whose justification we are concerned, grounds of attachment like ethno-national or religious identity are ruled out on principle. But the people of a liberal democracy attribute an overall constitutional goal to their states and become attached to it in virtue of the worthiness of that goal. Thus, as Professor Moses Finley famously observed, people in constitutional societies across history have tended to create valorizing mythologies around their constitutions. M.I. FinLey, THE USE AND ABUSE OF HISTORY 34-59 (1975). And I will argue in Part III that we can see similar attachment in the history of Black American constitutional thought.

53 See Habermas, supra note 42, at 774-75.

54 This assumes that members of these generations are appealing to their constitution as a thing they actually more-or-less endorse, as opposed to simply some unfortunate package of legal rules that, for example, because of collective action problems, they're stuck with. But people in constitutional societies generally seem to talk as if they do so endorse it. See generally FINLEY, supra note 52. Incidentally, the reader may already see the problems with these ideas in terms of excluded members of the community 
However, Professor Michelman has worries about that move as well. ${ }^{55}$ He convincingly argues that from the standpoint of constitutional patriotism, we must give some account of how citizens are to deal with the fact that they will often disagree as to what their constitutional institutions amount to. Moreover, the constitutional patriot is obliged to give an account of how citizens can accept those institutions in an incompletely theorized form, in the face of concrete interpretations of the underlying institutional values that might fill them out even in a way that violates their most fundamental individual values.

For an example of that problem, we might think of the American constitutional debate over abortion and the way that it highlights a stubborn difference between a fundamental value of bodily autonomy for some and a deep religious commitment for others. Can we really say that all of us in the United States, across generations, are members of the same people in virtue of our shared constitutional acceptance and adherence to an ongoing project of fulfilling and filling out the value claims underneath it, if some of us think that the Constitution guarantees abortion in order to protect women's bodily integrity and autonomy, while others of us think that such a position is tantamount to infanticide?

Professor Michelman's tentative and reluctant solution to this problem on behalf of the constitutional patriot is to posit a kind of partial agreement and good faith on a baseline liberal-democratic commitment shared by all that allows a people to at least recognize that they're playing the same game and accept the same abstract values, even in the face of deep disagreement about the concrete instantiations of those values. In short, the pro-lifers and the pro-choicers have to agree about enough to be able to think that one another are making mistakes about interpreting shared values. Pro-lifers and pro-choicers must not think that the former are actually into enslaving women and the latter are actually into infanticide, at least not under that description. They must merely think that one another are simply mistaken about the policies that their shared acceptance of women's right to bodily autonomy and rejection of infanticide collectively amount to.

It is worth quoting Professor Michelman at length here:

"Constitutional patriotism," it appears, is the morally necessitated readiness of a country's people to accept disagreement over the application of core constitutional principles of respect for everyone as free and equal, without loss of confidence in the univocal content of the principles, because and as long as they can understand the disagreement as strictly tied to struggles over

who have not had a chance to participate in this joint interpretation and may not endorse the constitutionthis will dominate my attention below.

55 Michelman, Morality, Identity, and 'Constitutional Patriotism', supra note 38, at 267-69. 
constitutional identity. And what explains that readiness, when and where it is found? The answer to that must be that conditions then and there warrant a level of confidence that the struggle over corporate identity occurs within a corporate identity that is already incompletely, but to a sufficient degree, known and fixed. The answer is, in other words, a cultural contingency-the cultural contingency, when and where it exists, that the corporate identity in question, however contested it may be in other respects, is already perceived by all concerned to fall within the class of morally conscientious (hence, in a Habermasian view, democratic-proceduralist) constitutional identities..$^{56}$

In other words, Professor Michelman suggests that a kind of civic unity is necessary for constitutional patriotism to serve as a case for democratic legitimation. We can understand the constitutional conception as, at bottom, directed at giving an account of the preconditions and democratic implications of such civic unity.

\section{A. A Model of the Constitutional Conception}

I will now sketch a model of a constitutional conception. It captures something like the endpoint of this Ackerman-Habermas-Michelman conversation with some of the particularities of discourse theory stripped out. However, the following merely represents my synthesis of the conception, not anyone else's argument in particular. I contend that popular sovereignty on the following model could work to reconcile a democracy to a constitution like ours (but, for reasons described below, not identical to it).

On the constitutional model, constitutional legitimation via popular sovereignty-and democratic legitimation of the political outcomes generated by such a constitution - should be understood as a process rather than an event. The model contains the following features: institutionalization, endorsement from those governed under those institutions, collective political action, learning or "development," and a shared cross-generational corporate identity. I elaborate upon those features below:

First is institutionalization: First-order democratic legitimacy is a property of fundamental political institutions (i.e., the organization of power, the system of basic rights), not day-to-day political outcomes, although those institutions in turn legitimate the day-to-day outcomes. Those institutions are

56 Id. at 269. In order to achieve this level of baseline unity, Professor Habermas's version of constitutional patriotism helps itself to a bunch of claims about basic human rights drawn from his broader discourse theory of political legitimation. Habermas, supra note 42, at 776-79. As I understand it, those rights set forth the ground rules that all players in the liberal-democratic game have to accept, even to (Professor Michelman would argue) get into a position by which they can start to take seriously the notion that they accept the same constitution which sets forth that society's interpretation of those ground rules. 
typically organized, via codification or tradition, into a system of values and institutions suitable to become broadly known and understood through the population. We can describe those organized institutions as a "constitution" and recognize that a constitution in this sense need not be a written document of fundamental law such as the U.S. Constitution or the German Basic Law, but can also encompass both unwritten fundamental legal institutions, as in Britain, and written documents expressing fundamental values that do not purport to legislate, such as the U.S. Declaration of Independence. ${ }^{57}$

Second, those governed under those institutions generally come to endorse that constitution in a nonpathological way, for example, as a result of learning, socialization, and experience with a shared practice of collective problem-solving under it (and not, for example, simply as a result of propaganda or state terror). They may endorse their constitution in the abstract, i.e., even if they disagree as to what their abstract values and institutions amount to, or disagree with the way in which the expressed values have been filled out in some cases. Such endorsement is not inconsistent with deeply divided parties, each claiming to be defending their true shared constitutional values.

Third, over their history, the people at large take an active role in shaping their constitutional institutions through collective political action. They organize both within and without the structure of formally sanctioned political activity to advocate for interpretations of the values underlying their constitutions that those organizing happen to hold. Moreover, if those values are threatened, for example, by antidemocratic forces, they engage in collective action to defend them. They enjoy a broad baseline of liberaldemocratic participatory rights, such as free speech and the electoral franchise, which facilitate their collective action.

Fourth is learning - or, perhaps, "development": Over time, these processes of collective action, plus the functioning of constitutional institutions, allow those institutions to adapt to accord with citizens' collective learning about those institutions' implications in terms of their values. This may happen either explicitly, such as by constitutional amendment, or implicitly, by changes in the set of interpretations of those values and institutions that citizens are willing to defend or landmark legislation. Collective action, in short, works, and it produces results that citizens tend to endorse as increasingly right over time.

\footnotetext{
57 Even where there is some constitutional text, it is not a conclusive source for a state's constitutional values. Rather, those values should be understood as a product of interpretation, in a broadly Dworkinian sense, in which we can read the state's system of political organization, its broad pattern of political outcomes, and its constitutional text (if any) together as capturing something like the values and aspirations of some constructive agent trying to pursue some vision of political life.
} 
Finally, these processes of endorsement, learning, and collective action promote the development of a shared corporate identity - a We the Peoplewhose members understand themselves to have that corporate identity across generations. That corporate identity is in part understood as encompassing the distinctive constitutional institutions of their state and the values that it serves and expresses.

\section{B. How the Constitutional Conception Solves the Deficiencies of the Mechanical Conception}

The constitutional conception allows those in democratic states, under plausible real-world circumstances, to understand themselves as part of a collective agent that has authored their constitution as well as day-to-day political outcomes brought about under it. It does so by redefining the object of authorship and the way it is achieved.

It will be helpful to consider the two problems in terms of two different demands of authorship. We the People must be able to understand ourselves both as the authors of our fundamental law and of our day-to-day political outcomes.

Under the constitutional conception, the people are the authors of their fundamental law for essentially the reasons given by Professors Ackerman and Habermas, as elucidated and modified by Professor Michelman. That is, the generations are coparticipants in a common enterprise of authorship rooted in a shared scheme of value. The founding generation (or a foreign hegemon, or whoever) wrote the constitution in question, it is true, but intervening generations have (a) developed its interpretation through their political acts within and without formal institutions (legislation, litigation, action in the streets) and (b) come to learn over time that their constitution is both useful (it helps them live together as a political community) and valuable (it instantiates values that they endorse). ${ }^{58}$ Over time, the people thus make the constitution their own.

Incidentally, this is a conception of how a constitution might grow into acceptance that is much older than Professor Habermas. As Aristotle (or perhaps one of his students; the attribution of this document is contested) suggests in Constitution of Athens, Solon gave the laws to Athens, then promptly left town for a decade, ordering them not to change anything in the

\footnotetext{
58 This is not to say that such claims are true for every constitutional society-it's possible for people not to endorse their constitution in these ways, or for them to come to do so purely as a matter of false consciousness or ideology rather than learning and benign socialization. This Section is a possibility claim - that we can realistically have states that satisfy the demands of popular sovereignty for these reasons_-not an actuality claim.
} 
meantime. ${ }^{59}$ It seems to me that what Solon was trying to do (really or mythically) was to give the Athenian people an opportunity to operate his laws, flesh them out with their own day-to-day choices, and come to understand their virtues - and in doing so, make them their own. If Plato in Crito is to be believed, this worked: as I have discussed elsewhere, the laws could be identified with the city itself and could serve as partly constitutive even of Socrates's own identity as an Athenian. ${ }^{60}$ In short, the constitution authors the demos, and the demos, thus constituted, authors the constitution. ${ }^{61}$

What of day-to-day outcomes? We ought to distinguish two categories of ways in which citizen wills over day-to-day outcomes might be frustrated in such a state, in order to see whether those frustrations are nonetheless consistent with popular sovereignty under the constitutional conception.

First are what we might call intentional frustrations. Our Constitution, as we've worked it out, allows nine people in black robes to decide that We the People do not get to, among other things, prohibit contraception, ${ }^{62}$ require private citizens to purchase health insurance, ${ }^{63}$ confer on the President the power to strike individual line items from the federal budget, ${ }^{64}$ define marriage as between a man and a woman, ${ }^{65}$ or undertake, in our public colleges, affirmative action for the sake of reparations, racial justice, or any purpose other than "diversity," 66 understood as the capacity of students of color to improve the educational outcomes of white students and economic and military outcomes for white-dominated institutions after graduation, as

59 Aristotle, Constitution of Athens, in 2 THE COMPLETE WORKS OF ARISTOTLE: THE REviSED OXFORD TRANSLATION 2341, 2346 para. 11 (Jonathan Barnes ed., F.G. Kenyon trans., 1984).

${ }^{60}$ Paul Gowder, What the Laws Demand of Socrates - and of Us, 98 MONIST 360, 366-67 (2015) (interpreting the argument of the Laws in Plato's Crito for why Socrates should not abscond from his sentence as appealing to the role of the laws of Athens both in individual identity-formation for citizens and in the collective maintenance of democratic life).

${ }^{61}$ I thank Mihailis Diamantis for suggesting the parallel construction here. To be clear, the constitution authors the demos by laying the foundational scheme of political value out of which its collective identity is composed as well as the minimum institutions necessary to sustain its identity as a People capable of constitutional authorship, such as basic inclusive human rights and participatory capacities. In Solon's case, the Athenian people already existed, and the original myth of its identity was probably not constitutional - the Athenians were said to have sprung from their native soil. See generally Vincent J. Rosivach, Autochthony and the Athenians, 37 CLASSICAL Q. 294 (1987). But the reading I give of Crito suggests that Solon's laws can be said to have reconstituted Athenian political identity on a legal basis. Gowder, supra note 60, at 366-67.

${ }^{62}$ Griswold v. Connecticut, 381 U.S. 479 (1965).

63 Nat'l Fed'n of Indep. Bus. v. Sebelius, 567 U.S. 519 (2012).

${ }^{64}$ Clinton v. City of New York, 524 U.S. 417 (1998).

65 Obergefell v. Hodges, 135 S. Ct. 2584 (2015).

${ }^{66}$ Grutter v. Bollinger, 539 U.S. 306 (2003). 
explained by Professor Derrick Bell's theory of interest convergence. ${ }^{67}$ The Electoral College, as we've worked it out via our state legislatures, requires states to give their electoral votes to the winner of the popular vote in their states and hence provides disproportionate power to elect presidents to rural voters and raises the repeated specter of presidents whose personalities and policies are rejected by the majority of the electorate.

To these complaints, the constitutional conception responds that the key words in the previous paragraph are "as we've worked it out." We did not have to read our Constitution to provide the power of judicial review; we do not have to continue to read it that way or to continue to allow the Supreme Court to impose these frustrations. Recall that we almost put a stop to it during the New Deal. ${ }^{68}$ Likewise, the way the Electoral College has been structured is an active matter of continuing politics - there are social movement efforts, like the campaign for a national popular vote compact, aimed at re-understanding the practical implementation of the Electoral College as written into the Constitution. ${ }^{69}$ They might eventually win-or, in terms of the constitutional conception, our generation as well as future generations might contribute to the continuing development of our Constitution, and that way make it our/their own. But win or lose, it is that same We the People continuing across time that has developed judicial review and the Electoral College over that time; we can rationally understand the consequences of those restraints as frustrations that we have imposed on ourselves - perhaps as instances of the self-binding considered by Professor Jon Elster ${ }^{70}$ - and thus understand ourselves as the authors of the outcomes of those frustrations.

The constitutional conception also requires a response to recalcitrant political outcomes that seem to be imposed by rogue institutions, such as a

67 Derrick Bell, Diversity's Distractions, 103 COLuM. L. REV. 1622, 1624-25 (2003) (pointing out that the compelling interest in educational diversity used to authorize affirmative action in state universities in Grutter attends not to the interests of subordinated minorities but to the interests of schools, employers, and the military).

68 See generally Laura Kalman, The Constitution, the Supreme Court, and the New Deal, 110 AM. HIST. REV. 1052, 1055 (2005) (describing debate among historians over the extent to which political pressure forced the Court to cease obstructing the New Deal).

${ }^{69}$ The idea of the popular vote compact is that since states get to choose how to allocate their electoral votes, a group of states controlling a majority of the electoral college can enter into an interstate compact according to which each will allocate their votes to the winner of the national popular vote- and hence implement the popular election of the president without constitutional amendment. See generally Susan Haigh, Connecticut Lawmakers Vote to Join Popular Vote Pact, AP News (May 6, 2018), https://apnews.com/64aa4481f15c4ceb926f609f02715c8d [https://perma.cc/2BCR-6X8W].

70 Jon Elster, Don't Burn Your Bridge Before You Come to It: Some Ambiguities and Complexities of Precommitment, 81 TEX. L. REV. 1751, 1754, 1758-60 (2003) (defining precommitment and raising questions about the extent to which constitution-making can be seen as an example of the phenomenon). 
Supreme Court that has positioned itself as a retrograde force standing in the way of a clear and extended popular will to the contrary, even on issues that might seem to be of fundamental constitutional value, and in ways that do not seem to be amenable to resolution by ordinary politics. Let us not forget that Lincoln's resort to the thwarting complaint was in response to the evil of Dred Scott. ${ }^{71}$ Let us call those "unintentional frustrations," frustrations of popular control over political outcomes that we can't plausibly attribute to inconsistencies in the will of a demos extending across time. (The line between intentional and unintentional frustrations may not be all that firm.)

Here, too, the constitutional conception has such an answer, represented most saliently by Professor Ackerman's theory of constitutional moments: where frustrations mount too high, the people have a reserve capacity to overcome the difficulties of their democratic machinery and impose their will on their institutions. The difficulty of doing so, and the requirement of genuine mass alignment and mobilization to do so, establish a kind of constitutional credibility for these moments. ${ }^{72}$ Thus, while institutions that are built to frustrate short-term electoral results or popular desires might occasionally go rogue, even for an extended period of time, citizens of states that feature this kind of reserve capacity in the people can nonetheless retain confidence in their ultimate ability to command authorship in the long run. ${ }^{73}$

\footnotetext{
71 See supra note 8 and accompanying text.

72 Bruce Ackerman, Constitutional Politics/Constitutional Law, 99 YALE L.J. 453, 461-62 (1989) (describing the "specially onerous higher lawmaking system" achievable by mass movement politics capable of generating constitutional legitimacy as act of the demos (emphasis omitted)).

73 A similar point may be applied to unintentional frustrations more broadly. Rational ignorance, for example - the (alleged) fact that citizens of large and modern democracies lack incentive to learn how to operate their political machinery - isn't something that we could plausibly attribute to an act of ongoing authorship of We the People. See supra note 31 and accompanying text. However, even if citizens are unavoidably incapable of achieving some end through their democratic processes in one instance, they can still understand themselves as authors of the overall complex of outcomes that includes the frustrating outcome and the sociopolitical factors that lead to it. (For example, one might argue that our rational ignorance is a product of our large constituencies that lead to a minuscule likelihood of individual votes making a difference, plus our governmental, economic, and policy complexity; our large constituencies and our complexity are probably a product of our astounding wealth and governmental capacity; they are the price we pay for the other victories we have achieved as a People.) Moreover, they can still understand themselves as having the capacity over time to revise that outcome, or to shape the rest of their outcomes to accommodate it and incorporate it into the larger scheme of goals that they attribute to their demos. Or they may understand themselves as having a second-order capacity to develop their own first-order ability to collectively influence political outcomes, for example, by intervening on the educational system and the structure of political decision-making.

To be fair, my responses to both intentional and unintentional frustrations still impose some mechanistic political efficacy constraints on democratic systems. Social movements have to work sometimes, even ordinary political machinery still has to work sometimes —or else the claim that a state's institutions are under continual reexamination and redevelopment is false, and the claim that the people have the capacity to correct recalcitrant outcomes with constitutional moments is false. However, the
} 
The constitutional conception understands a state's institutions as a combination of its day-to-day outcomes in the aggregate, over time, as those outcomes flesh out the values and more fundamental and abstract institutions that make up the state's constitution; that complex of outcomes and values is under continual reexamination and redevelopment across generations. Popular authorship of the Constitution, and the laws enacted under it, is a process, not a result. And this process can include judicial review.

\section{Black Exclusion and the Failure of the Constitutional Conception}

However, the constitutional conception cannot legitimate states where some class of people is persistently and illegitimately excluded. ${ }^{74}$ By "excluded" I mean to capture, but not limit the analysis to, the experience of Black Americans across the centuries..$^{75}$ In this Section, I argue that Black Americans have been persistently excluded from the demos and that this exclusion is fatal to the legitimating ambitions of the constitutional conception. In the next Part, I articulate a theory, drawing from a tradition of Black American constitutional thought, that may provisionally redeem the constitutional conception and, with it, the American Constitution.

\section{The Persistent Exclusion of Black Americans}

American constitutional history is a history of democratic exclusionsthe Native American, the Woman, and of course the Slave. Indeed, scholars have argued that We the People is constructed in opposition to such categories. In the words of Professor Nikhil Singh, "the ideal national subject has actually been a highly specific person whose universality has been fashioned from a succession of those who have designated his antithesis,

constitutional conception is consistent with a lot less popular outcome-directing capacity than is the mechanical conception.

${ }^{74}$ To be sure, the question of who gets to be part of the demos that is the subject of popular sovereignty is always highly contested. See, e.g., Sarah Song, The Boundary Problem in Democratic Theory: Why the Demos Should Be Bounded by the State, 4 INT'L THEORY 39 (2012) (giving one account of whom should be included and whom excluded). Sometimes, it's perfectly acceptable to exclude individuals or groups from the demos - Vladimir Putin, for example, is not entitled to vote for the U.S. President — denying him a vote doesn't make the United States less democratic, for Putin is not part of the demos. But there are difficult boundary cases - how much, for example, should lawfully resident aliens be included in the American demos? Yet we do not need an overall theory of who is appropriately entitled to be part of the People to identify some cases where a country obviously gets it wrong. While there might be difficult boundary cases, there are easy cases as well, and real-world states have routinely blown the easy cases, by, for example, enslaving people, disenfranchising racial and religious minorities as well as women, and so on.

75 See Iris Marion Young, InClusion AND Democracy 13 (2000) (defining exclusion as "political processes that claim to be democratic but which some people reasonably claim are dominated by only some of those whose interests are affected by them"). 
those irreducibly non-national subjects who appeared in the different guises of slave, Indian, and, at times, immigrant." 76

As Professor Singh also argues, the condition of Black Americans stands apart even within the collection of exclusions that have made up America, for Black Americans represent "the anomaly of an exclusion that was at once foundational to and located within the polity." ${ }^{77}$ Put bluntly, how can We the People include Black Americans when the Constitution of 1788 was written against a background conception of the demos in which Black meant not People but property? ${ }^{78}$ Moreover, important parts of the Constitution of 1788 were written in order to preserve the capacity of slaveholding states to continue to exclude Black Americans from the polity - the most blatant, of course, being the three-fifths "compromise" (between slaveholding Whites and non-slaveholding Whites), according to which those who held Black Americans as slaves could vote for three-fifths of them in Congress.

The Constitution of 1870 at least purported to offer formal equality to Black Americans. Many Black Americans could hold an authorship role in the constitutional reforms of the Reconstruction period due to the brief flowering of black suffrage, as well as the prior service of thousands of Black Americans in the Union Army that forced those reforms upon the South. ${ }^{79}$

76 Nikhil Pal Singh, Black Is a Country: Race and the Unfinished Struggle for DEMOCRACY 21 (2004). The same idea in terms of individual psychology can be found in the work of Ralph Ellison. See Jack Turner, Awakening to Race: Ralph Ellison and Democratic Individuality, 36 PoL. THEORY 655, 664-68 (2008) (reading Ellison in terms of existentialism, in the suggestion that white identification and white supremacy are coping mechanisms for white people to deal with the uncertainty of the world around them and their own identities). In Ellison's words, as quoted by Turner:

Since the beginning of the nation, white Americans have suffered from a deep inner uncertainty as to who they really are. One of the ways that has been used to simplify the answer has been to seize upon the presence of black Americans and use them as a marker, a symbol of limits, a metaphor for the "outsider." Many whites could look at the social position of blacks and feel that color formed an easy and reliable gauge for determining to what extent one was or was not American.

Id. at 666 (quoting Ralph Ellison, What America Would Be Like Without Blacks, TimE, Apr. 6, 1970, at $54,55)$.

77 SingH, supra note 76 , at 22

78 As we shall see, this grim vision of the Constitution has been contested by many Black Americans. See infra Part III.

79 One hundred eighty thousand Black Americans served in the Union Army. Eric Foner, Rights and the Constitution in Black Life During the Civil War and Reconstruction, 74 J. AM. HIST. 863, 864 (1987). On the authorial capacity exercised by Black Americans in the brief period of suffrage, see generally Michael D. Cobb \& Jeffrey A. Jenkins, Race and the Representation of Blacks' Interests During Reconstruction, 54 POL. RES. Q. 181 (2001) (describing election of Black members of Congress following Black suffrage and distinctive voting patterns of those representatives). Indeed, Congress procured the Fourteenth Amendment by placing the South under military rule, requiring Southern states to admit Black voters, and making ratification of the Fourteenth Amendment a condition of readmission. See generally 
But, of course, this was stolen away by the resurgence of white supremacy in the South, aided and abetted by the Supreme Court ${ }^{80}$ - and so whither Black authorship?

The Second Reconstruction, in the form of the civil rights revolution, was largely a product of Black activism on the streets. However, at the time, Black Americans suffered from a substantial deficit of authorial capacity in the form of formal institutions, due to the massive disenfranchisement of Black voters and discrimination against Black citizens in all sectors of the economy and the educational system. Once again, the gains from the labor of Black Americans and their allies promised the future of Black inclusion in We the People. Yet the rise of the war on drugs and mass incarceration once again broke those promises. Countless Black Americans have been disenfranchised by the discriminatory application of antidrug laws and the ensuing civil consequences of conviction, as well as, of course, being subject to the direct arbitrary violence of the state. ${ }^{81}$ Indeed, we could argue that

Gabriel J. Chin, The "Voting Rights Act of 1867": The Constitutionality of Federal Regulation of Suffrage During Reconstruction, 82 N.C. L. REV. 1581, 1589-91 (2004) (summarizing the Military Reconstruction Act); James E. Bond, Ratification of the Fourteenth Amendment in North Carolina, 20 WAKE FOREST L. Rev. 89, 101-10 (1984) (describing the course of events in North Carolina in which the Fourteenth Amendment was rejected before military rule, when Blacks were deprived of the vote, but was swiftly ratified by the reconstructed government elected under Black suffrage). On the idea of the nation as re-founded by the Reconstruction Amendments, see, for example, Thurgood Marshall, The Constitution's Bicentennial: Commemorating the Wrong Document?, 40 VAND. L. REv. 1337, 1340 (1987) ("While the Union survived the Civil War, the Constitution did not. In its place arose a new, more promising basis for justice and equality, the fourteenth amendment ...."). See generally Garrett Epps, Second Founding: The Story of the Fourteenth Amendment, 85 OR. L. REv. 895 (2006) (arguing for a revolutionary interpretation of the Fourteenth Amendment). But see Michael W. McConnell, The Fourteenth Amendment: A Second American Revolution or the Logical Culmination of the Tradition?, 25 LOY. L.A. L. REV. 1159 (1992) (arguing for conception of the Fourteenth Amendment as a continuation of constitutional law present in the original); Laurence Tribe, Bicentennial Blues: To Praise the Constitution or To Bury It?, 37 AM. U. L. REv. 1, 3 (1987) ("But the Constitution of Thurgood Marshall is also incomplete. It denies its own roots - and its own still unresolved contradictions - in the process of professing its progressive character. To celebrate the Civil War amendments without acknowledging the basic framework of carefully separated and divided powers into which those amendments fit is to overlook the 18th-century institutional structures which alone made it possible for Congress, in the late 19th century and again after the mid-20th, to implement the amendments' guarantees."). The tradition of thought beginning with Frederick Douglass-which I will draw out infra in Part III- would not register surprise at the capacity of the Reconstruction Amendments to be presented both as revolution and as continuation, just as Douglass himself recognized, see infra notes 134-142 and accompanying text, both that the Constitution contained a latent promise of equality and that it would require a radical break with the past to fulfill that promise.

${ }^{80}$ Most notoriously, see United States v. Cruikshank, 92 U.S. 542 (1876), which struck down federal authority to respond to racial terrorism and use of force to prevent Black suffrage, and Giles v. Harris, 189 U.S. 475 (1903), in which the Court refused to enforce the Fifteenth Amendment against blatant discriminatory application of suffrage criteria in Alabama.

${ }^{81}$ See UGGEN ET AL., infra note 99; see also infra notes 100-109 and accompanying text (discussing these statistics). 
Black Americans continue to embody the contrast against which citizenship is defined. Professor Angela Davis argues that the incarceration of Black Americans helps define the rights of liberal democracy by illustrating their opposite, and that as slavery is social death, imprisonment is civil death. ${ }^{82}$

I contend that Black Americans continue to be excluded from the American demos. To illustrate this exclusion, I focus on electoral exclusion (among many other kinds of exclusion) and, in particular, the disproportionate effect of felony disenfranchisement and its roots in multiple layers of anti-Blackness. ${ }^{83}$ Felon disenfranchisement falls particularly heavily on people of color, including Black Americans, because of the mass incarceration policies that have been both intended and applied in a racially discriminatory fashion. ${ }^{84}$ As Nixon aide John Ehrlichman confessed:

The Nixon campaign in 1968, and the Nixon White House after that, had two enemies: the antiwar left and black people. You understand what I'm saying? We knew we couldn't make it illegal to be either against the war or black, but by getting the public to associate the hippies with marijuana and blacks with heroin, and then criminalizing both heavily, we could disrupt those communities. We could arrest their leaders, raid their homes, break up their meetings, and vilify them night after night on the evening news. Did we know we were lying about the drugs? Of course we did. ${ }^{85}$

82 ANGela Y. Davis, The Meaning of FreEdom: AND Other Difficult Dialogues 125-26, 175 (2012).

${ }^{83}$ That being said, there are numerous other ways in which Black Americans have been excluded from the demos, such as by physical segregation and the way in which such segregation supports social stigma and isolation. See generally Paul Gowder, Racial Classification and Ascriptive Injury, 92 WASH. U. L. REV. 325, 363-85 (2014) (describing system of racial segregation, government culpability for same, and stigmatic injury imposed by it). I limit the focus of this Section to electoral disenfranchisement only because full inclusion in formal electoral institutions seems like the bare minimum to say that a group is genuinely treated as a member of a democratic People, but do not by this limitation mean to assert that the end of disenfranchisement would be sufficient to achieve inclusion.

${ }^{84}$ See generally Michelle AleXANDER, THE New Jim CROW: MASS INCARCERATION IN THE AgE of Colorblindness (rev. ed. 2012); David Cole, No EQual Justice: RaCe and Class in the American Criminal Justice System (1999); Policing the Black Man: Arrest, Prosecution, and IMPRISONMENT (Angela J. Davis ed., 2017); Dorothy E. Roberts, The Social and Moral Cost of Mass Incarceration in African American Communities, 56 STAN. L. REV. 1271 (2004). In recent years, some scholars have questioned Alexander's specific causal account of mass incarceration. See, e.g., JOHN F. Pfaff, Locked In: The True Causes of Mass Incarceration-and How to Achieve Real REFORM (2017) (providing evidence that changes in prosecutorial charging decisions rather than drug policy have driven mass incarceration). However, the argument of this Article does not depend on tracing the pathway from anti-Blackness to mass incarceration through drug policy in particular.

85 Dan Baum, Legalize It All: How to Win the War on Drugs, HARPERS MAG. (Apr. 2016), https://harpers.org/archive/2016/04/legalize-it-all [https://perma.cc/37C4-9H3W]. After this story, several former Nixon Administration officials issued a statement denying that Ehrlichman was serious about this confession. Hilary Hanson, Nixon Aides Suggest Colleague Was Kidding About Drug War Being Designed to Target Black People, HufF. Post (Mar. 25, 2016, 5:32 PM), https://www. 
The connections between overcriminalization and disenfranchisement are obvious: vast numbers of Black Americans are legally forbidden from voting due to criminal convictions. I assert that this disenfranchisement is a key form of contemporary exclusion from the American demos.

The history of felon disenfranchisement laws, particularly in the South, is deeply tainted by racial discrimination. The Southern states enacted felon disenfranchisement laws, in conjunction with laws aimed at criminalizing activities thought to be engaged in predominantly by Black Americans, as part of the rollback of Reconstruction and the start of Jim Crow. ${ }^{86}$ Even the repeal of disenfranchisement laws shows signs of being race-based: Professor Angela Behrens and others find that states with more Black Americans in prison since 1940 have been less likely to repeal laws disenfranchising former felons. ${ }^{87}$

The category of "infamous" crimes has often been the predicate of disenfranchisement. Professor Pippa Holloway has convincingly argued that the concept of infamous crimes served as a continuation of the same social process by which Blackness has been defined as the opposite of

huffpost.com/entry/richard-nixon-drug-war-john-ehrlichman_n_56f58be6e4b0a3721819ec61 [https://perma.cc/K44U-E39J].

86 Elizabeth A. Hull, The Disenfranchisement of Ex-Felons 18-21 (2006) (recounting history of Reconstruction-era enactment of disenfranchisement laws in the South and evidence that those laws targeted Black citizens); AleXAnder Keyssar, The Right to Vote: The Contested History OF DEMOCRACY IN THE UNITED STATES 89, 111-12, 356-62, tbl.A.15 (rev. ed. 2009) (contextualizing disenfranchisement laws with other restrictions on right to vote targeted against Black citizens in the south, including "poll taxes, cumulative poll taxes (demanding that past as well as current taxes be paid), literacy tests, secret ballot laws, lengthy residence requirements, elaborate registration systems, confusing multiple voting-box arrangements, and eventually, Democratic primaries restricted to white voters"); JEFF MANZA \& Christopher UgGen, Locked Out: Felon DisenfRANCHISEMENT AND AMERICAN DEMOCRACY 41-68 (with Angela Behrens, 2006) (discussing the racial origins and explanations of felon disenfranchisement laws in the United States); Alec C. Ewald, "Civil Death": The Ideological Paradox of Criminal Disenfranchisement Law in the United States, 2002 WIS. L. REV. 1045, 1090-95; see also Hunter v. Underwood, 471 U.S. 222, 229 (1985) (striking down-finally, in 1985-a provision of Alabama's Constitution disenfranchising those convicted of crimes of moral turpitude, enacted in 1901, on the ground that the 1901 revisions had the express goal "to establish white supremacy in this State" and had succeeded by disenfranchising a disproportionate number of Black Americans); Ratliff v. Beale, 20 So. 865, 868 (Miss. 1896) (openly admitting that the purpose of the Mississippi Constitution of 1890 was "to obstruct the exercise of the franchise by the negro race" and that the motive for the choice of crimes to bring under disenfranchisement was to select those thought likely to be committed by Black Americans).

87 Angela Behrens et al., Ballot Manipulation and the "Menace of Negro Domination": Racial Threat and Felon Disenfranchisement in the United States, 1850-2002, 109 AM. J. Soc. 559, 591-94 (2003); see also MANZA \& UGGEN, supra note 86, at 67. 
Americanness. ${ }^{88}$ Infamous crimes have been equated to felonies, ${ }^{89}$ but have also historically been associated with crimes evidencing a lack of personal honor, such as bigamy and perjury. ${ }^{90}$ She traces the history of the category of infamy and its expressive use as a way to define noncitizenship, arguing that it was rooted in the distinction between freemen and slaves in English history-a distinction which transferred to American slaves..$^{91}$ In the course of extending this infamy to freed Black Americans, for example, Professor Holloway recounts the selective identification of crimes associated with Blackness and the elevation of those crimes to infamous status after emancipation. ${ }^{92}$ In other words, American slaves were inherently infamous, and after emancipation, states retained the infamy of former slaves by disenfranchising them, predicating that disenfranchisement on crimes associated with racialized beliefs about slavery and infamy. ${ }^{93}$ Disenfranchisement both depended on the subordinated status of Blackness and reinforced that subordinated status.

As recently as 2016, the Iowa Supreme Court held that the application of the Iowa Constitution's "infamous crime" clause was sufficient to permit disenfranchisement of a citizen who had "delivered" cocaine to another. ${ }^{94}$ The Court so ruled over a dissent that pointed out the racially discriminatory history of the "infamous crimes" standard as well as the disparate impact of felony disenfranchisement on Black Americans. ${ }^{95}$

There is reason to believe that this disenfranchisement has led to genuine political consequences. Professor Angela Davis argues that felon disenfranchisement was responsible for the 2000 election of George W. Bush as President, in virtue of his narrow margin of victory and the disproportionate criminalization of Black Americans, in a context in which Florida disenfranchised hundreds of thousands of people. ${ }^{96}$ Similarly,

\footnotetext{
88 PipPa Holloway, Living IN INFAMY: FELON DiSFRANCHISEMENT AND THE HiSTORY OF AMERICAN CITIZENSHIP 151-52 (2014).

89 See, e.g., Griffin v. Pate, 884 N.W. 2d 182, 202-03 (Iowa 2016) (ruling, on the basis of historically-rooted analysis, that infamous crimes under the Iowa Constitution includes all felonies).

90 Holloway, supra note 88, at 4.

91 Id. at 54-78; see also Ratliff, 20 So. at 868 (admitting to that strategy).

92 For more on the English category of "freeman" as a status descriptor, see PAUL GowDER, THE RULE OF LAW IN THE REAL WORLD 130-37 (2016).

93 HollowAY, supra note 88 , at 78.

94 Griffin, 884 N.W. 2d at 183.

95 Id. at 216-17 (Appel, J., dissenting)

96 President Bush won by a mere 537 votes. DAVIS, supra note 82, at 177. According to the Roper Center, reporting on exit poll results, $90 \%$ of Black Americans voted for Al Gore in that election. ROPER CTR. FOR Pub. Op. Res., CORnell UnIV., How Groups VOTED IN 2000, https://ropercenter.cornell. edu/polls/us-elections/how-groups-voted/how-groups-voted-2000 [https://perma.cc/2UH6-TZGK] [hereinafter How GROUPS VOTED IN 2000] (based on exit polling data). Based on this study, Professor
} 
Professors Christopher Uggen and Jeff Manza identify seven Senate elections since 1978 in which the result arguably would have changed absent felon disenfranchisement. ${ }^{97}$

Unfortunately, this problem has persisted into recent elections..$^{98}$ According to a report prepared by several sociologists for the Sentencing Project, an estimated 6.1 million people were disenfranchised in the United States pursuant to a felony conviction in 2016, of whom 2.2 million were Black. ${ }^{99}$

To illustrate the degree of Black exclusion from ordinary electoral processes, let us look at several of the key battleground states in the 2016

Davis's claim is wholly plausible. Moreover, before that election, Florida purged a number of eligible voters from the rolls. News accounts have suggested that the list of felons - on the basis of which a number of voters were purged-was rife with errors and overrepresented Black voters. See, e.g., Lisa Getter, Florida Net Too Wide in Purge of Voter Rolls, L.A. TIMES (May 21, 2001, 12:00 AM), https://www.latimes.com/archives/la-xpm-2001-may-21-mn-620-story.html [https://perma.cc/F7KKRUJH] (recounting voter purges in Florida 2000 electorate containing non-felons and, in some counties, disproportionate representation of Black Americans, including as much as 66\% Black people in MiamiDade County).

97 Christopher Uggen \& Jeff Manza, Democratic Contraction? Political Consequences of Felon Disenfranchisement in the United States, 67 AM. Soc. REv. 777, 787-90 (2002) (identifying Senatorial elections in Virginia in 1978, Texas in 1978, Kentucky in 1984, Florida in 1988, Wyoming in 1988, Georgia in 1992, and Kentucky in 1998 as likely to have changed under the counterfactual of no disenfranchisement). I note that all of these states except Wyoming are in the South, and all but Wyoming and Kentucky were in the Confederacy. For the significance of that fact in terms of the continuing influence of antebellum politics on contemporary race relations, see, for example, Acharya et al., The Political Legacy of American Slavery, 78 J. POL. 621 (2016) (showing empirically that county-level differences in prevalence of slavery are still correlated to contemporaneous attitudes in racial politics). For a more subtle racial impact of felon disenfranchisement, see Brianna Remster \& Rory Kramer, Shifting Power: The Impact of Incarceration on Political Representation, 15 Du BoIs REV. 417 (2018) (demonstrating, via analysis of Pennsylvania data, distortion in state-level voting power away from Black citizens due to the disparate incarceration of Black Americans in rural communities away from home, where they are disenfranchised but nonetheless counted as residents for the purpose of representation in those districts).

98 That being said, there may be some grounds for hope that this will change, as Florida in 2018 repealed much of its former felon disenfranchisement. Tim Mak, Over 1 Million Florida Felons Win Right To Vote With Amendment 4, NPR (Nov. 7, 2018, 2:46 AM), https://www.npr.org/2018/11/07/665031366/over-a-million-florida-ex-felons-win-right-to-vote-withamendment-4 [https://perma.cc/P87U-CYJ8]. However, Florida's implementation of this Amendment has been subject to some controversy, with critics alleging that implementation legislation requiring former felons to pay financial penalties associated with their convictions before being re-enfranchised constitutes a poll tax. See, e.g., Katrina vanden Heuvel, A New Poll Tax Will Suppress Florida's Voting Reform, WASH. POST (May 14, 2019), https://www.washingtonpost.com/opinions/2019/05/14/new-polltax-will-suppress-floridas-voting-reform/?utm_term=.e406ebalf01f [https://perma.cc/KZG8-7ETC] (arguing that financial penalty payment requirement is unjust, in part because Florida imposes exorbitant financial penalties on the convicted).

99 Christopher Uggen et al., Sentencing Proj., 6 Million lost Voters: State-Level ESTIMATES OF FELONY DISENFRANCHISEMENT, 2016, at 3, 16 (2016), https://www.sentencingproject.org /wp-content/uploads/2016/10/6-Million-Lost-Voters.pdf\#page=17 [https://perma.cc/D234-5TT8]. 
election. Combining data from the Sentencing Project report and the New York Times state-by-state vote totals produces the following table:

TABle 1: Disenfranchisement IN THE 2016 PRESIDENTIAL EleCtion ${ }^{100}$

\begin{tabular}{|l|c|c|c|}
\hline \multirow{2}{*}{ State } & \multicolumn{2}{|c|}{ Disenfranchised } & \multirow{2}{*}{ Trump Margin } \\
\cline { 2 - 3 } & All & Black & \\
\hline MI & 44,221 & 23,679 & 10,704 \\
\hline WI & 65,606 & 22,447 & 22,748 \\
\hline PA & 52,974 & 25,596 & 44,292 \\
\hline FL & $1,686,318$ & 499,306 & 112,911 \\
\hline
\end{tabular}

Trump, of course, won 306 electoral votes to Clinton's 232. Looking at the table above, we see that the number of Black Americans disenfranchised in both Michigan and Florida was larger than Trump's margin of victory in those states. While we cannot know how prisoners or disenfranchised former felons would have voted, in view of the overwhelming share of Black votes received by Clinton in 2016, there is at least a realistic possibility that enfranchising those who were disenfranchised in those states, by permitting both those incarcerated and former felons to vote, would have changed the results in Florida and Michigan, causing forty-five electoral votes, and the White House, to change hands. ${ }^{101}$

Obviously, this is not to say that the disenfranchisement of Black Americans via racially discriminatory mass incarceration caused Trump's election. We cannot know what really would have happened. However, there are many other ways that disenfranchisement of Black Americans potentially still affects electoral results today-particularly in terms of the control of state legislatures, and, with it, redistricting processes.

The Sentencing Project report reveals some truly astonishing numbers. ${ }^{102}$ The first two columns of the following chart are their felon disenfranchisement figures for some of the most striking states; the third is my calculation of the percentage of non-Black citizens disenfranchised in 2016:

\footnotetext{
100 The numbers presented in the first two columns include both felons disenfranchised while in prison and felons disenfranchised afterward, per post-release disenfranchisement provisions in those states that have them. Id. at 15-16. The last column represents my Trump-Clinton subtractions from the state-by-state vote totals reported by the New York Times. Presidential Election Results: Donald J. Trump Wins, N.Y. TIMES (Aug. 9, 2017, 9:00 AM), https://www.nytimes.com/elections/2016/ results/president [https://perma.cc/7REB-8Q2D].

101 According to the Roper Center, $89 \%$ of Black Americans voted for Clinton. How GROUPS VOTED IN 2000, supra note 96 (reporting on CNN exit polls).

102 See UgGen ET AL., supra note 99.
} 
N ORTHW ESTER N UNIVERS ITY L A W RE VIEW

TABle 2: Relative Disenfranchisement Rates In the 2016 PRESIDENTIAl EleCtion $^{103}$

\begin{tabular}{|l|c|c|c|}
\hline State & $\begin{array}{c}\text { Black } \\
\text { Disenfranchised }\end{array}$ & $\begin{array}{c}\text { General Population } \\
\text { Disenfranchised }\end{array}$ & $\begin{array}{c}\text { Non-Black } \\
\text { Disenfranchised }\end{array}$ \\
\hline KY & $26 \%$ & $9 \%$ & $8 \%$ \\
\hline TN & $21 \%$ & $8 \%$ & $6 \%$ \\
\hline VA & $22 \%$ & $8 \%$ & $5 \%$ \\
\hline FL & $21 \%$ & $10 \%$ & $9 \%$ \\
\hline WY & $17 \%$ & $5 \%$ & $5 \%$ \\
\hline All U.S. & $\mathbf{7 . 4 4 \%}$ & $\mathbf{2 . 4 7 \%}$ & $\mathbf{1 . 8 \%}$ \\
\hline
\end{tabular}

These figures show that in 2016 upwards of four times as many Black Americans were disenfranchised as a percentage of the population.

Nor is felon disenfranchisement the only egregious form of ongoing, race-based disenfranchisement. On July 29, 2016, the Fourth Circuit identified blatant racial discrimination in changes to North Carolina's election laws. ${ }^{104}$ The reason? "[T] he legislature requested and received racial data as to usage of the practices changed by the proposed law," and then turned around and eliminated those voting provisions that advantaged Black voters. ${ }^{105}$ Specifically, it asked for data on types of ID used by voters and then decreed that the types of ID predominantly used by Black voters would no longer be sufficient for identification at the polls. ${ }^{106}$ It asked for data on race and early voting and then eliminated the period most predominantly used by Black voters. ${ }^{107}$ It asked for data on race and same-day registration, found that Black voters disproportionately used it, and then eliminated it. ${ }^{108}$ There was not a lot of subtlety there.

Also not subtle: the 2015 closure of DMV offices in predominantly Black Alabama counties, ultimately reversed only under pressure from the U.S. Department of Transportation; unsurprisingly, this closure came on the

103 The calculation is carried out by subtracting the total Black disenfranchised from the total disenfranchised population to get the total non-Black disenfranchised population, doing the same with population as a whole, then dividing the former from the latter. All except total U.S. are rounded to nearest whole percentage. Population figures are derived from the "VAP" (voting age population) figures in the Sentencing Project data tables.

104 N.C. State Conference of NAACP v. McCrory, 831 F.3d 204, 214-15 (4th Cir. 2016) ("[T]he new provisions target African Americans with almost surgical precision ... we can only conclude that the North Carolina General Assembly enacted the challenged provisions of the law with discriminatory intent.").

$105 I d$. at 216.

$106 I d$.

107 Id.

${ }^{108} I d$. at 217. 
heels of a voter ID law. ${ }^{109}$ Then again, Alabama isn't exactly known for its friendliness to Black voters: in 2011, state legislators were recorded complaining about a gambling ballot measure because, well, read it yourself:

A confederate warned: "Just keep in mind if [a pro-gambling] bill passes and we have a referendum in November, every black in this state will be bused to the polls. And that ain't gonna help." ... The participants predicted: "Every black, every illiterate" would be "bused on HUD financed buses." 110

Later, one of the legislators also described Black citizens of Alabama as "aborigines." 111 Incidentally, it will surprise few readers who have made it this far to learn that the stereotype underlying this particular act of bigotry - the supposition that Black Americans are particularly susceptible to social vices associated with lack of self-control, like gambling, and hence particularly motivated to support a pro-gambling bill — also featured heavily in the choices of crimes to subject to disenfranchisement in the postReconstruction period. For some strange reason, Southern Democrats seemed to be particularly convinced that prospective Black voters couldn't resist stealing chickens (although the impoverishment of freed people in the South didn't help) and used this alleged lack of self-control of Black Americans as a reason to impose disenfranchisement for this crime. ${ }^{112}$ Apparently these tropes are still here and still drive attempts at voter suppression.

In the 2018 election, Georgia's secretary of state, Brian Kemp, ran for governor against Stacey Abrams. Abrams was vying to be Georgia's first Black governor and the first Black woman to be a governor of any state in America. Prior to the election, Kemp engaged in a massive wave of registration cancellations and blockages. In particular, the state wrote an "exact match" voter registration process into law in 2017113 - doubtless

109 Vann R. Newkirk II, What's Missing from Reports on Alabama 's Black Turnout, ATLANTIC (Dec. 7, 2017), https://www.theatlantic.com/politics/archive/2017/12/can-doug-jones-get-enough-blackvoters-to-win/547574_[https://perma.cc/PR33-GWN7] (reporting on findings that DMV closures were predominantly in the "Black Belt" region of Alabama).

110 United States v. McGregor, 824 F. Supp. 2d 1339, 1345 (M.D. Ala. 2011) (internal citations omitted) (finding legislative witnesses lacked credibility in bribery prosecution related to gambling bill because of racially discriminatory motivations).

111 Id. ("In a separate conversation, during which [Senator] Lewis asked whether the predominantly black residents of Greene County were 'y'all's Indians?,' [Senator] Beason responded by derisively referring to blacks as 'Aborigines."') (internal citations omitted).

112 HoLlowAY, supra note 88, at 73-75 (quoting a number of examples).

113 O.G.C.A. \$ 21-2-220.1(b) ("In the event that the name . . does not match information about the applicant on file ... the applicant shall nevertheless be registered to vote but shall be required to produce proof of his or her identity ... before the time that such applicant requests a ballot ... .); see also Ga. Coalition for the People's Agenda v. Kemp, 347 F. Supp. 3d 1251, 1255-57 (N.D. Ga. 2018) (recounting enactment of exact match). 
thanks in no small part to the end of Voting Rights Act preclearance in Shelby County v. Holder ${ }^{114}$ - pursuant to which, tiny variations in voter information, like variations in how last names are hyphenated, could lead to a voter's registration being put on hold. Kemp put some 53,000 registrations on hold; according to the press, $70 \%$ of those whose registrations were put on hold were Black, compared to $32 \%$ of Georgia's citizens; moreover, Kemp canceled hundreds of thousands of registrations for "inactivity." ${ }_{115}$ Although I do not have a 2018 estimate, according to the Sentencing Project data, 144,546 Black Georgians were disenfranchised for felonies in 2016, well over half of Georgia's 248,751 total felon disenfranchisements. ${ }^{116}$ According to the New York Times, Brian Kemp's margin of victory over Stacey Abrams was 54,723 votes. ${ }^{117}$ After the election, Abrams all but called it stolen, recounting " 1.5 million people purged [from voter rolls], 53,000 [votes] put on hold, 3,000 denied the right to register as new citizens." 118

These are merely the few cases where courts were able to do something, or, as in the Georgia situation, where the media has at least caught the suppression efforts, because of the presence of smoking-gun evidence. We cannot know what lies in the shadows.

\section{The Failure of the Constitutional Conception}

Even after rejecting the mechanical conception of popular sovereignty, the constitutional conception still requires that citizens be included in the formal institutions of electoral politics to have a full role in the crossgenerational conversation the constitutional conception contemplates. But the facts recounted above entail that Black Americans have been and continue to be excluded from the demos - not, obviously, to the same extent as in Jim Crow, but excluded nonetheless.

114 Shelby Cty. v. Holder, 133 S. Ct. 2612, 2631 (2013). See Jurisdictions Previously Covered by Section 5 at the Time of the Shelby County Decision, U.S. DEP'T JUSTICE, https://www.justice.gov/ crt/jurisdictions-previously-covered-section-5 [https://perma.cc/EVS7-5LU6] (listing Georgia among jurisdictions covered by Voting Rights Act preclearance formula at the time the Supreme Court struck it down in Shelby County).

115 All of these details come from Ben Nadler, Report: Georgia's Secretary of State Is Blocking 53,000 Voter Registrations As He Runs for Governor, TIME (Oct. 10, 2018), https://news. yahoo.com/report-georgia-apos-secretary-state-231158238.html [https://perma.cc/TXZ4-G7MC].

116 UGGEN ET AL., supra note 99, at 15-16.

117 Georgia Election Results, N. Y. TiMES (May 15, 2019, 2:09 PM), https://www.nytimes.com/interactive/2018/11/06/us/elections/results-georgia-elections.html [https://perma.cc/7RF7-9XGX].

118 Jessica Taylor, Stacey Abrams Says She Was Almost Blocked from Voting in Georgia Election, NPR (Nov. 20, 2018, 5:00 AM), https://www.npr.org/2018/11/20/669280353/stacey-abrams-says-shewas-almost-blocked-from-voting-in-georgia-election [https://perma.cc/W64X-AF8W]. Bracketed additions are NPR's. 
I do not aim here to give a full theory of exclusion. However, I can say a few things about the concept as I see it. Exclusion seems to me to have both expressive and practical components. Practically speaking, a group is excluded when it lacks the formal and informal supports for participation in the ongoing conversations about a state's institutions contemplated by the constitutional conception, as when its members have been formally or informally disenfranchised, subject to arbitrary violence or criminalization, or subject to economic discrimination and expropriation that undermines their capacity for collective political activity. Expressively speaking, a group is excluded when a state's institutions have been operated such that the group is either treated as a nonmember in writing or in practice - as it were, written out of We the People. Expressive exclusion occurs when a state's institutions have been fleshed out in order to express a social hierarchy, within which there are genuine members - who are accorded the rights of membershipand subordinate classes. ${ }^{119}$

I claim that, in particular, the expressive meaning of Black exclusion makes it difficult for anyone, of whatever racial background, to understand Black Americans as co-authors of America's political outcomes.

We can understand the exclusion of so many Black Americans from the electoral process as creating an electorate that is identifiably less Black than the general population, and hence imposing expressive injury on Black Americans in general. Why should those who are excluded see themselves as co-citizens? How can non-Black citizens understand Black citizens as citizens in a world in which their participatory capacity, as well as those interests of Black Americans that are achievable through the operation of America's ordinary political machinery, is systematically disadvantaged? ${ }^{120}$

Members of an excluded group cannot participate in a state's satisfaction of the criteria of the constitutional conception. They have no reason to endorse institutions that express the aim of their subordination. The development of those institutions lacks, except by accident or by force, their participation in its learning and development. Thus, members of an excluded group cannot understand themselves as authors of the political outcomes in such a state - and, since the constitutional conception depends on all in the demos being able to understand themselves as authors, it cannot (at least so

\footnotetext{
119 For a more complete account of what it means for law to express the subordinate status of some group of people, see Paul Gowder, Equal Law in an Unequal World, 99 IowA L. REV. 1021 (2014).

120 For another discussion of the expressive significance of felon disenfranchisement, see R.A. Lenhardt, Understanding the Mark: Race, Stigma, and Equality in Context, 79 N.Y.U. L. REV. 803, 91624 (2004). On the problem of exclusion, criminal justice, and Black Americans more generally, see I. Bennett Capers, Rethinking the Fourth Amendment: Race, Citizenship, and the Equality Principle, 46 HARV. C.R.-C.L. L. REV. 1 (2011) (arguing that current constitutional criminal procedure doctrine fails to treat people of color as equal citizens).
} 
far as the analysis has gotten to this point, for I shall aim to redeem it in the next Part) legitimate states that engage in persistent and illegitimate exclusion. ${ }^{121}$

Professor Seyla Benhabib, more than other scholars in the tradition of the constitutional conception, has wrestled with the implications of exclusion in the course of developing her cosmopolitan account of her version of "jurisgenerative politics." 122 On Professor Benhabib's argument, the conception of the people in a democratic state is itself subject to intergenerational, discursive revision. In her words: "Although the demos, as the popular sovereign, must assert control over a specific territorial domain, it can also engage in reflexive acts of self-constitution, whereby the boundaries of the demos can be readjusted." ${ }^{23}$ Yet the cases she considers are primarily those relating to migration, that is, when some acknowledged outsider enters into a pre-constituted political community that was, presumptively, legitimate before migration. By contrast, the American case is one in which the political community was incomplete and for that reason illegitimate from the start. ${ }^{124}$ Black Americans fought in the American

121 Moreover, as I noted above, the constitutional conception can only preserve popular authorship in the face of mass frustrations if there is some reserve capacity in the people to take the reins of political outcomes; exclusion means some groups of people unjustifiably have less of that capacity.

122 Seyla Benhabib, The Rights of Others: Aliens, Residents, AND Citizens 181 (2004) ("Jurisgenerative politics refers to iterative acts through which a democratic people that considers itself bound by certain guiding norms and principles reappropriates and reinterprets these, thus showing itself to be not only the subject but also the author of the laws." (emphasis omitted)). The term "jurisgenerative" originated with Professor Robert M. Cover, Foreword: Nomos and Narrative, 97 HARV. L. REV. 4, 15 (1983), though Professor Benhabib sometimes uses the term differently. I confess that I find Professor Cover's use of the term somewhat obscure, though Professor Judith Resnik has offered a more lucid explanation. Judith Resnik, Living Their Legal Commitments: Paideic Communities, Courts, and Robert Cover, 17 YALE J.L. \& HUMAN. 17, 18 (2005) (interpreting Cover to describe a kind of tension between communal pluralism and the universalistic aspirations of liberal legality). The term is also associated with Professor Michelman, and he, like Professor Benhabib, uses the term to refer to the capacity of a population, through law, to become a demos capable of giving itself law. See Frank Michelman, Law's Republic, 97 YALE L.J. 1493, 1502 (1988) ("One possible way of making sense of this is by conceiving of politics as a process in which private-regarding 'men' become public-regarding citizens and thus members of a people. It would be by virtue of that people-making quality that the process would confer upon its law-like issue the character of law binding upon all as self-given."). Professor Benhabib has, however, sometimes suggested that her version of jurisgenerative politics is drawn from Cover's and has connected the two. See, e.g., Seyla Benhabib, Claiming Rights Across Borders: International Human Rights and Democratic Sovereignty, 103 Am. POL. SCI. REv. 691, 700-02 (2009) (using concept of jurisgenerativity to connect local practices of Muslim communities and transnational law).

123 BENHABIB, supra note 37, at 35-36.

124 To be sure, the case of migration is not nearly as clean as that in practice, for, as Professor Benhabib points out, France's migration is in part due to its colonial and imperial adventures in Africa. $I d$. at 68 . But I note that there was nonetheless a France before that colonization, whereas there was no America before slavery. 
Revolution and have never stood as foreigners to the United States. ${ }^{125}$ Thus, Benhabib's conception of progressive inclusion cannot redeem the American demos on its own. We need a theory of constitutional popular sovereignty not for a We the People that must decide how to integrate outsiders, but for a We the People that has never been properly formed in the first place.

Moving from constitutional legitimacy to constitutional application, Professor Jamal Greene has made points similar to those articulated in this Section: on his argument, the fact of Black exclusion is an objection to originalism, because originalism purports to commit constitutional theory to a backward-looking interpretation of the text. Professor Greene argues that this is incompatible with what I call the constitutional conception: if we justify following the commands of prior generations by their "normative continuity" with the People of the present, then we simply cannot read those commands pursuant to a backward-looking perspective. ${ }^{126}$ I agree, and now in Part III, I argue that Frederick Douglass and his intellectual heirs articulated an account of the Constitution that can permit us to adopt the forward-looking perspective and begin to build normative continuity.

\section{FREDERICK DOUGLASS'S CONSTITUTIONALISM AND CYNICAL FAITH}

The remainder of this Article will assume that the reader agrees that Black Americans are still excluded from We the People - the argument that follows may not move the reader who rejects this claim. I will further assume that some version of the constitutional conception is the correct theory of popular sovereignty, at least for countries like the United States; that is, more-or-less legalistic states that claim liberal-democratic status. ${ }^{127}$ I shall call such states aspirant liberal democracies. An aspirant liberal democracy is a state with constitutional institutions sufficient to support the elements of the constitutional conception described in the previous Part, even if they are characterized by so much exclusion that they do not actually deserve the title.

The fact of persistent exclusion seems to permit one of two responses for a citizen concerned to live under only democratic laws. First, one might throw up one's hands and reject the institutions of one's state. Such a citizen

\footnotetext{
125 Of course, many American slaves were originally foreigners, kidnapped or sold from their own nations, but the United States never accorded them the rights or status associated with foreigners, such as the protection of embassies or support for their own linguistic, religious, or cultural traditions.

126 Jamal Greene, Originalism's Race Problem, 88 DENV. U. L. REV. 517, 520-521 (2011). Professor James Fox has brilliantly taken up Greene's challenge to articulate a "counterpublic" originalism which centers the way that Black Americans have interpreted the constitution in understanding its original meaning. James W. Fox, Jr., Counterpublic Originalism and the Exclusionary Critique, 67 ALA. L. REV. 675, 677 (2016).

127 By "legalistic states," I just mean states with legal systems purporting to comport with the rule of law.
} 
might grudgingly obey the laws because they are enforced by force, depart the territory, or strive for revolutionary change.

Alternatively, one might retain some conditional attachment to the constitutional institutions - not based in the supposition that there is a genuine We the People capable of legitimating those institutions, but based on their potential for grounding the creation of such a people in the future. That is, such an attachment may rely on the potential for the inclusion of the excluded, and, with that inclusion, the true constitution of the people, where "constitution" is understood in the active sense, as the act of constituting that people.

I will draw from Frederick Douglass and his intellectual heirs in a robust Black American tradition of constitutional thought to argue that just such a conditional attachment to the constitution of an aspirant liberal democracy is available even in the face of persistent exclusion. Examining how Douglass chose attachment, the reasoning he offered, and the stance he took toward the Constitution, with elaborations and variations from later Black American thinkers, reveals an attitude which, I contend, is appropriate for all Americans to take toward their Constitution. It permits attachment to such a constitution for the purpose of pressing the institutions it establishes to actually work toward the values it expresses. If this effort is successful, it permits that constitution to be legitimated, despite its origins, by a kind of retroactive authorship, by and on behalf of the excluded, potentially redeeming its corrupted history. ${ }^{128}$

\section{A. Douglass on the Constitution and Slavery}

While Black American political and legal thought is very diverse and has adopted a wide range of stances toward the U.S. Constitution, ${ }^{129}$ there is a distinctive strain of Black American thought that has focused on the way in which the United States has failed to live up to its own fundamental values. Recently, Professor Chris Lebron has elucidated this strain of thought in the context of the intellectual heritage of the Movement for Black Lives; his

\footnotetext{
128 It is important to note that while this Article focuses on Black responses to the Constitution, Black political and legal thought is not the only source for an egalitarian reframing of American constitutional legitimacy. While the exclusion of Black Americans has been a defining feature of American legal history, a full rebuilding of the demos must also take into account the perspectives of other subordinated and excluded groups. See, e.g., Maggie Blackhawk, Federal Indian Law as Paradigm Within Public Law, 132 HARV. L. REV. 1787, 1789 (2019) (arguing for a reading of American constitutional law that more fully integrates the encounter between the United States government and Native American nations).

129 Indeed, Douglass, my main source for these ideas, has come under criticism for naïveté, not just from his contemporaries, but from ours. See, e.g., Charles W. Mills, Whose Fourth of July? Frederick Douglass and "Original Intent”, in FrEDERICK DOUGLASS: A CRITICAL READER 100-42 (Bill E. Lawson \& Frank M. Kirkland eds., 1999).
} 
words are apt on the subject. Describing Douglass and Ida B. Wells, he writes:

Both thinkers challenged Americans to think more clearly and consistently about the principles on which their citizenship was founded and the ways those principles were violated when blacks demanded equality. Actions of contemporary activists ... also, following Douglass's lead, have invoked the principles of American democracy to call upon citizens to account for the quality and content of their civic and moral convictions. ${ }^{130}$

We could describe this, perhaps, as an "internal critique," except that usually when we talk about internal critique, we refer to critique of a system from the standpoint of a participant in the system. As we shall see, the Black Americans who have levied this critique have often only conditionally understood themselves as participants in, as opposed to captives of, the American system. Hence, it is not quite the same thing as internal critique as the term is conventionally used. But it also is not just a second-person or pure outsider's allegation of hypocrisy either, "you're not treating me the way your purported values would dictate," for Black Americans have never stood as completely external to the American system. For example, the style of critique Professor Lebron describes does not, it seems to me, resemble that of an atheist scolding a Christian for not following Christ's example. It is something in between purely internal and purely external critique.

Hence, I will call the stance taken by this strain of thought "claimant critique." A claimant critic is a person who claims inclusion in a system, where that system is predicated on a set of values, and those values ground the claim for inclusion; the critic criticizes the system for betraying those values by not including the critic. The critique is paired with a claim for inclusion based on moral standing and a shared fate, and a conditional

130 Christopher J. Lebron, The MAKING OF BLACK LiVES MATTER: A BRIEF History OF AN IDEA 34 (2017). The methodological approach of this Section, which combines intellectual history with normative argument, is greatly indebted to the fine example set by Professor Lebron, as well as NICK Bromell, The Time Is Always Now: Black Thought and the Transformation of U.S. DEMOCRACY 3 (2013). Both scholars model a kind of interpretive intellectual history which treats much the same strain of Black thought as I discuss here. With the recognition that while there are many other strains of Black thought, I, like Professors Lebron and Bromell, suggest the selective interpretation of this one line can reveal truths that may help us understand the American experience and the abstract values, such as democracy and equality, that America has always claimed. Intellectual historians of Black American thought often, following a classic article by Professor Bernard Boxill, describe Douglass as part of the "assimilationist" tradition, to be contrasted with a "separatist" one. See Bernard Boxill, Two Traditions in African American Political Philosophy, in AFrICAN-AMERICAN PERSPECTIVES AND Philosophical Traditions 119 (John P. Pittman ed., 1997). This classification seems too broad to capture the distinctive constitutional ideas found in Douglass's later thought and his successors in that tradition. Thus, while this Section could be understood as describing a subcategory of the assimilationist tradition, I do not find the assimilationist/separatist typology useful here. 
endorsement of the values. We can imagine the claimant critic saying something like this: "We're in this together, because you dragged my ancestors over here, and I kind of like these values you assert; why don't you follow them and treat me as a full participant in the scheme of social relations that is supposed to instantiate those values - which, critically, purport to include values of equal inclusion." 131

Not only is this strain of thought a set of moral claims, but, at least on Douglass's example, it is also a set of legal claims. To see how this works, let us begin with a passage from a speech of Douglass's in Glasgow, Scotland in 1860, entitled The Constitution of the United States: Is It Pro-Slavery or

131 Douglass most perfectly expressed the idea of claimant critique in his Fourth of July speech. As Bromell points out, Douglass simultaneously assumes both an insider and an outsider stance, both emphasizing the distance that was present between himself and his audience and at the same time claiming, repeatedly, the status of fellow citizen. BROMELL, supra note 130, at 110-11; see also HoANG Gia PHAN, Bonds of CitiZENSHIP: LAW AND the LABORS OF EMANCIPATION 144-45 (2013) (fleshing out the point further). Consider, as representative, the following passage:

Fellow-citizens, pardon me, allow me to ask, why am I called upon to speak here to-day? What have I, or those I represent, to do with your national independence? Are the great principles of political freedom and of natural justice, embodied in that Declaration of Independence, extended to us? and am I, therefore, called upon to bring our humble offering to the national altar, and to confess the benefits and express devout gratitude for the blessings resulting from your independence to us?

Would to God, both for your sakes and ours, that an affirmative answer could be truthfully returned to these questions! Then would my task be light, and my burden easy and delightful. For who is there so cold, that a nation's sympathy could not warm him? Who so obdurate and dead to the claims of gratitude, that would not thankfully acknowledge such priceless benefits? Who so stolid and selfish, that would not give his voice to swell the hallelujahs of a nation's jubilee, when the chains of servitude had been torn from his limbs? I am not that man. In a case like that, the dumb might eloquently speak, and the "lame man leap as an hart."

But such is not the state of the case. I say it with a sad sense of the disparity between us. I am not included within the pale of this glorious anniversary! Your high independence only reveals the immeasurable distance between us. The blessings in which you, this day, rejoice, are not enjoyed in common.-The rich inheritance of justice, liberty, prosperity and independence, bequeathed by your fathers, is shared by you, not by me. The sunlight that brought light and healing to you, has brought stripes and death to me. This Fourth July is yours, not mine. You may rejoice, I must mourn. To drag a man in fetters into the grand illuminated temple of liberty, and call upon him to join you in joyous anthems, were inhuman mockery and sacrilegious irony. Do you mean, citizens, to mock me, by asking me to speak to-day? If so, there is a parallel to your conduct. And let me warn you that it is dangerous to copy the example of a nation whose crimes, towering up to heaven, were thrown down by the breath of the Almighty, burying that nation in irrevocable ruin! I can to-day take up the plaintive lament of a peeled and woe-smitten people!

Frederick Douglass, The Meaning of July Fourth for the Negro (July 5, 1852), in FredERICK DOUGLASS: SElECted SPEECheS AND WRitingS 188, 194 (Philip S. Foner ed., abridged \& adapted by Yuval Taylor, 1999) [hereinafter DougLASS].

Observe how Douglass juxtaposes the form of address, "Fellow-citizens," which he repeats numerous times through the speech, with the second-person form of address paired with the facts that emphasize the "immeasurable distance" between himself and those ostensible "fellow-citizens," and thus renders that address less one of mutual respect than of biting sarcasm. 
Anti-Slavery? ${ }^{132}$ This speech is the fullest statement of his (late-career) position on the Constitution and slavery.

In this speech, Douglass aimed to refute the Garrisonian position on the Constitution. The Garrisonians were fellow abolitionists, but they thought that the Constitution was an irrevocably proslavery document and hence advocated for its abandonment. ${ }^{133}$ Douglass, at least by this point, disagreed and thought the Constitution could be redeemed. The bulk of the speech is a careful textual analysis in which Douglass raises numerous seemingly sinister clauses and argues that each need not be read to permit slavery, despite the evil meaning that both slaveholders and Garrisonians would put on it. But his work is not yet done, for the Constitution is also a statement of values, and he sees an irrevocable conflict between Constitutional values and slavery, a conflict which forbids the conventional, proslavery, reading of those passages:

Let us look at the objects for which the Constitution was framed and adopted, and see if slavery is one of them. Here are its own objects as set forth by itself:"We, the people of these United States, in order to form a more perfect union, establish justice, ensure domestic tranquility, provide for the common defence, promote the general welfare, and secure the blessings of liberty to ourselves and our posterity, do ordain and establish this Constitution of the United States of America." The objects here set forth are six in number: union, defence, welfare, tranquility, justice, and liberty. These are all good objects, and slavery, so far from being among them, is a foe of them all. ${ }^{134}$

These values become a guide to constitutional interpretation. His argument is not just that it would be immoral to read the Constitution to be a proslavery document, but that legal interpretive principles, according to which a law is to be read in accordance with its goals and the values underlying it, also forbid such a reading:

The speaker at the City Hall laid down some rules of legal interpretation. These rules send us to the history of the law for its meaning. I have no objection to such a course in ordinary cases of doubt. But where human liberty and justice are at stake, the case falls under an entirely different class of rules. There must

132 Frederick Douglass, The Constitution of the United States: Is It Pro-Slavery or Anti-Slavery? (Mar. 26, 1860), in Douglass, supra note 131, at 380-90. Other extended explications of Douglass's approach to the Constitution include an editorial in The North Star entitled The Constitution and Slavery, in Douglass, supra note 131, at 129-33, and an 1857 speech entitled The Dred Scott Decision, in Douglass, supra note 131, at 344-58. After emancipation, he continued the same theme in a speech entitled The Civil Rights Case, in DougLaSs, supra note 131, at 685-93, condemning the Civil Rights Cases, see 109 U.S. 3 (1883).

133 See generally Paul Finkelman, Affirmative Action for the Master Class: The Creation of the Proslavery Constitution, 32 AKRON L. REV. 423, 424-25 (1999) (describing the Garrisonian position).

134 Douglass, The Constitution of the United States, supra note 132, at 379, 387. 
be something more than history-something more than tradition. The Supreme Court of the United States lays down this rule, and it meets the case exactly"Where rights are infringed - where the fundamental principles of the law are overthrown - where the general system of the law is departed from, the legislative intention must be expressed with irresistible clearness." The same court says that the language of the law must be construed strictly in favour of justice and liberty. Again, there is another rule of law. It is - Where a law is susceptible of two meanings, the one making it accomplish an innocent purpose, and the other making it accomplish a wicked purpose, we must in all cases adopt that which makes it accomplish an innocent purpose. Again, the details of a law are to be interpreted in the light of the declared objects sought by the law. I set these rules down against those employed at the City Hall. To me they seem just and rational. I only ask you to look at the American Constitution in the light of them, and you will see with me that no man is guaranteed a right of property in man, under the provisions of that instrument. If there are two ideas more distinct in their character and essence than another, those ideas are "persons" and "property," "men" and "things." Now, when it is proposed to transform persons into "property" and men into beasts of burden, I demand that the law that contemplates such a purpose shall be expressed with irresistible clearness. The thing must not be left to inference, but must be done in plain English. ${ }^{135}$

While Douglass was not a lawyer, he applies interpretive principles that closely track techniques used in constitutional law even today. Political theorist Anthony Ives suggests that Douglass's method of interpretation tracks legal philosopher Lon Fuller's methodology, insofar as it understands the formal character of law to operate as a constraint on its capacity to do great evil. ${ }^{136}$ As I read the Glasgow speech, it more closely resembles the "moral reading" of the Constitution advanced by legal theorists such as Ronald Dworkin ${ }^{137}$ and James Fleming, ${ }^{138}$ and, more broadly, Dworkin's general value-laden technique of legal interpretation and legal theorist David Dyzenhaus's argument that common law judges may use their interpretive powers to resist unjust acts of parliament. ${ }^{139}$ Douglass clearly sees the

\footnotetext{
135 Id. at 386-87.

136 Anthony Lister Ives, Frederick Douglass's Reform Textualism: An Alternative Jurisprudence Consistent with the Fundamental Purpose of Law, 80 J. POL. 88, 98-99 (2018).

137 See Ronald Dworkin, Freedom's Law: The Moral Reading of the AMERICAN CONSTITUTION 2-12 (1996) (describing and defending "moral reading" of Constitution).

138 See James E. Fleming, Fidelity to Our IMPERfect Constitution: For Moral Readings AND AGAINST ORIGINALISMS 74-81 (2015) (describing and defending "philosophic approach" to constitutional interpretation).

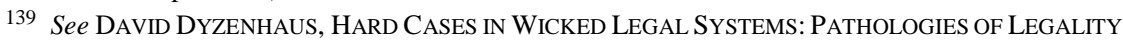
143-44 (2d ed., 2010) (describing the way in which apartheid warped the South African legal system and the ways that common-law judging permitted legal resistance to it); DAVID DYZENHAUS, THE CONSTITUTION OF LAW: LEGALITY IN A TIME OF EMERGENCY 4 (2006) (arguing that common-law judges have the authority to uphold the rule of law against legislative overreach in times of emergency).
} 
Constitution as a purpose-driven document, in which the Preamble describes a set of values in pursuit of which the operative text must be interpreted. As Ives also explains, the purposes of the Constitution are explicitly not the purposes of the people who wrote it. ${ }^{140}$ Rather, the purposes are those attributed to We the People in the text. ${ }^{141}$ We might say that Douglass modeled the United States Constitution as representing the constructive aims of an agent-We the People-imperfectly attempting to fulfill the values stated in the Preamble.

Douglass does not just draw on the Preamble, but also focuses on specific operative passages to suggest that even ordinary textualist legal readings of those passages, if carried out faithfully, prohibit slavery:

They go everywhere else for proof that the Constitution is pro-slavery but to the Constitution itself. The Constitution declares that no person shall be deprived of life, liberty, or property without due process of law; it secures to every man the right of trial by jury, the privilege of the writ of habeas corpus - that great writ that put an end to slavery and slave-hunting in England - it secures to every State a republican form of government. Any one of these provisions, in the hands of abolition statesmen, and backed up by a right moral sentiment, would put an end to slavery in America. ${ }^{142}$

Thus, he denied the dominant white supremacist constitutional interpretation and insisted that the Constitution could be interpreted in terms of the values to which it appealed - an interpretation inconsistent with slavery. That is, Douglass endorsed the United States Constitution-not as it had been interpreted by the officials who administered the juridical infrastructure of slavery, but as it could be interpreted by a faithful adherent to the values it purported to write into law. ${ }^{143}$

Still, Douglass did not believe that the mere ordinary application of legal interpretive rules through the courts would bring about the end of

140 Ives, supra note 136, at 90-93. Professor Phan helpfully elaborates the literature on Douglass's constitutionalism and the idea that he rejected originalism in favor of a kind of pure textualism and usefully places Douglass in the context of debates over the role of intent that were happening both then and now. PHAN, supra note 131, at 107-41.

141 This cannot just be a flavor of originalism focusing on the original intent of ordinary citizens rather than the Framers, for Douglass would have had no particular reason to think or claim that ordinary people had any different attitude to slavery than did the Framers. It must be a constructive purpose, derived solely from the claims of purpose written in the document itself as well as the substantive proliberty provisions on which Douglass relied (such as the prohibition on bills of attainder and the protection of the writ of habeas corpus).

142 Douglass, The Constitution of the United States, supra note 132, at 388.

143 Professor Phan also points out a passage in Life and Times in which Douglass offers a similarly expansive reading of the limited terms of the Emancipation Proclamation. PHAN, supra note 131, at 20607. Although, as I read the passage in question, it is ambiguous whether Douglass's expansive interpretation of it focused on its quasi-legal content or what he terms its "moral power." 
slavery. The hand of "abolition statesmen" would be required, and, of course, abolition statesmen were not fully in control until after a bloody war was fought. Moreover, he recognized that the unbroken course of interpretation of the Constitution had been proslavery:

But to all this it is said that the practice of the American people is against my view. I admit it. They have given the Constitution a slaveholding interpretation. I admit it. They have committed innumerable wrongs against the Negro in the name of the Constitution. Yes, I admit it all; and I go with him who goes farthest in denouncing these wrongs. But it does not follow that the Constitution is in favour of these wrongs because the slaveholders have given it that interpretation. ${ }^{144}$

So he must have known that bringing about the constitutional interpretations he proposed within ordinary legal processes was a tall order. The Supreme Court wasn't about to wake up one morning and declare slavery unconstitutional in a context in which slaveholders held immense political power. Moreover, he surely must have known that the plantation owners would not give up their slaves peacefully, law or no law. There is an implicit kind of hopefulness (or what I will in a moment call "cynical faith") in this. The Constitution seems to express, to Douglass, something worthwhile, which he cannot but believe in, even as he knows that the ordinary, lawful institutional paths to achieving that value aren't likely to come about.

As Professor Lebron explains, Douglass challenged the American people to live up to the ideals "that the founding committed the everyday American to uphold." 145 That is, their public identity, via their Constitution, committed the (not-yet properly constituted) American demos to those ideals. Moreover, Professor Lebron also suggests, I think wisely, that Douglass understood American constitutional institutions, and the interpretations and practices they generated, to serve an educative role. ${ }^{146} \mathrm{An}$ antislavery interpretation of the Constitution would potentially help bootstrap a moral education for Whites - they couldn't see the evil of slavery on their own, but, perhaps, if they were shown how the values that supposedly formed the foundation of their own fundamental institutions condemned that evil, their experience operating institutions expressing those values could teach them to hate slavery.

144 Douglass, The Constitution of the United States, supra note 132, at 388.

145 LEBRON, supra note 130, at 12-16.

146 Id. at 14-16 (arguing that Douglass saw American legal institutions as shaping the character of the American people, to "educate and habituate the citizens over which they held sway."). 
Professor Nicholas Bromell traces this approach to American institutions to Douglass's time in exile- - his time in the British Isles revealed that people of other nations esteemed the Declaration of Independence as a statement of universal human value, and, it seems, inspired in him a deeper attachment to those values. ${ }^{147}$ In Professor Bromell's words, "the experience of being nationless allowed Douglass to reconceive the meaning of his nation and of its founding document, the Declaration." ${ }^{148}$ Professor Bromell thus reads Douglass as a cosmopolitan constitutional patriot, prefiguring Professor Benhabib's articulation of similar ideas. ${ }^{149}$

We can add to Professor Bromell's point an insight from Professor Hoang Phan, who points out that Douglass, in a reply to John C. Calhoun, offers his textualist constitutional interpretation through the device of "a man from another country." 150 Professor Phan reads this to emphasize the textualism and anti-originalism of Douglass's constitutional thought, but I would add that it is significant that Douglass posits the eyes of a foreigner, of one coming to the Constitution and the values it expresses untainted by the corruptions of slavery - just as the very foreigners with whom Douglass interacted could have seen it.

In effect, Douglass strives to achieve the things that the constitutional conception describes. He strives to endorse the Constitution and to make it a thing worth endorsing, consistent with the true meaning of its words as read from an outsider perspective and thus without the taint of slavery. ${ }^{151} \mathrm{He}$ strives to interpret the Constitution in a way that makes it fit to participate in a process of social learning. And he strives to be fully included in the We the People who get to shape it. In doing so, he gives voice to the values

147 BROMELL, supra note 130, at 82-85 (recounting Douglass's experience with observing display of Declaration of Independence in places of honor in homes in Ireland and arguing that Douglass perceived capacity of Declaration to serve as universalistic statement of human value).

148 Id. at 83 .

149 Strikingly Professor Bromell also finds this idea on what we might have at one point (around 2008, say) mistakenly conceived as the opposite end of the arc of Black American history, a speech of President Obama's at West Point in which he described the capacity of other countries too to claim the ideals in our Declaration. Id. at 138-39. For a transcript of the speech in question, see Barack Obama, Commencement Address at the U.S. Military Academy at West Point (May 22, 2010), in TIME (June 2, 2016), https://time.com/4340845/obama-commencement-speech-transcript-west-point [https://perma.cc/R392-6U54] ("We believe, 'that all men are created equal, that they are endowed by their Creator with certain unalienable rights, that among these are life, liberty and the pursuit of happiness' ... It is a belief that has been claimed by people of every race and religion in every region of the world.").

150 PHAN, supra note 131, at 3-5, 109-12.

151 I deliberately equivocate here between the outsider perspective of the slave and the outsider perspective of the foreigner, both of which Douglass adopts, in order to claim insider status on the basis of the words read as an outsider. In other words: reading the Constitution as an outsider would allows us to understand that the enslaved ought to have been treated as insiders, as members of the demos. 
underlying the Constitution and expresses at least the possibility of a relationship of mutual affirmation between the American people as a whole and their constitutional values.

\section{B. A Model of Black Constitutional Claimant Critique}

As with the constitutional conception, I shall sketch a model of the version of Black American constitutionalism which I defend and which is rooted in Douglass's Glasgow speech. After describing this model in the abstract, I will further illustrate it through important exemplars of Black American constitutional thought after Douglass. I will then conclude by describing its implications for restoring a kind of provisional legitimacy to aspirant liberal democratic constitutionalism, even in the face of exclusion, by correcting the most important oversights of the constitutional conception.

Rather than an account of popular sovereignty as such, this Section is a model of a stance toward the American Constitution and its democratic claims which can serve as critique of, and an amendment to, the constitutional conception. The elements of this model are thus arranged to correspond to the equivalent elements of the model of the constitutional conception articulated above in six parts.

First, a recognition that Black Americans have been, and continue to be, excluded from full inclusion in We the People, that group of Americans on whose behalf American constitutional institutions and political outcomes purport to speak. This recognition is combined with a claim for inclusion in that People, or demos, not just on the basis of a moral claim to inclusion, but also on the basis of a constitutional reading. Correctly interpreted and applied in accordance with the values it purports to uphold, the Constitution already commands the full inclusion of Black Americans. ${ }^{152}$

Second, a conditional attachment to the Constitution: if it actually becomes applied - as it can be - to include Black Americans, then it is worth keeping. That is, an evaluative attitude toward the (idealized) Constitution as worth preserving and promoting in virtue of its capacity to provide both a normative framework grounding that claim to inclusion as well as an institutional framework for filling out that inclusion in the form of concrete

152 In terms of the constitutional model, this is a recognition that the values of the Constitution are not institutionalized - the state's system of political organization and pattern of outcomes cannot be interpreted as the actions of an agent pursuing the values that the Constitution claims it is. In terms of our actual constitutional law today, full inclusion might entail, for example, doctrinal modifications requiring more aggressive scrutiny of racially disparate criminal justice practices or felon disenfranchisement laws, and the overruling of Shelby County v. Holder. 
legal rights and protections. This amounts to a positive vision of the Constitution as a map from the excluded present to the included future. ${ }^{153}$

Third, a commitment to real-world collective political action to bring about that inclusion and hence to reconstitute the demos and the concomitant recognition that, in the absence of such action, the inclusion will not occur and the Constitution will not be redeemed.

Fourth, a vision of the Constitution as educational. The values it utters, and the way in which those both within and without the currently acknowledged membership of the demos fill out those values through understanding as well as political action, can educate the populace as a whole about how their shared life ought to be lived.

Fifth, a specifically identity-composing consequence to that constitutional claim: only with the inclusion of Black Americans will We the People actually exist as a coherent collective identity. And only then will Americans of any and all races have a stable and fully formed social identity. Inclusion creates the constitutional demos - and in the absence of this inclusion, the partial demos is doomed to failure.

Finally, a cynical faith. This is the simultaneous holding of two attitudes toward the Constitution. First, a difficulty believing that the Constitution will ever be allowed to fulfill its potential, due to the conflicting interests of those in power. Second, the experience of seeing brief glimmerings of its potential and hence a lingering belief in that potential and willingness to work to pursue it.

In the following Sections, I will pull out some salient examples of this stance. This is a highly selective pass through intellectual history-my claim is not that these thinkers are representative of the entirety of Black American constitutional thought, or even that the passages I draw out are properly representative of the thought of each of the thinkers discussed. Rather, I claim merely that we can see a continuous strand of intellectual engagement with America's Constitution and nascent/potential demos woven through the passages I discuss, and it is a strand worth holding onto (and worth weaving into the constitutional conception from Part II); the texts I have discussed here were chosen for their capacity to saliently illustrate this line of thought.

153 Professor Hendrik Hartog sees the connection between these first two pieces of the model (although I disagree with his characterization of it as "unsettling"): on his account, many groups who have aspired to constitutional inclusion in the United States have asserted that present constitutional interpretations grounding their exclusion (and, as Hartog weirdly emphasizes, vesting rights - like the "right to segregate"-in others) have always been illegitimate. This claim implies the "threat" of delegitimation of the constitutional order as a whole if it cannot correct these grievous errors. Hendrik Hartog, The Constitution of Aspiration and "The Rights That Belong to Us All," 74 J. AM. Hist. 1013, 1024-25 (1987). 
Different elements of this stance have appeared in the words of different thinkers across time and place. While I will attempt to maintain a broadly chronological approach, I shall move in and out of various thinkers and time periods as necessary to draw out the relatedness of the ideas articulated. Ultimately the narrative below repeatedly cycles through Black American history to draw out different elements of constitutional claimant critique.

\section{Claimant Critique and Cynical Constitutional Faith in Black American Thought}

Let us begin with Douglass's antebellum contemporaries in the North. In 1838, Black citizens of Pennsylvania were called upon to argue against a state constitutional revision which would limit the suffrage to whites. ${ }^{154}$ Shortly beforehand, the state supreme court had misread the prior constitution to include a racial limitation of suffrage despite its complete absence from the text. ${ }^{155}$ Abolitionist Robert Purvis and others penned a response to the case and to the proposed amendment.

Unlike Douglass, Purvis and his collaborators do not focus on a moralized reading of the Constitution, but they nonetheless appeal to American foundational values and to the historical standing of Black Pennsylvanians, since, in the North, such a standing could more easily be demonstrated. They express a faith in the [state] constitution as written to be able to overcome the misreadings of the court:

The Convention of 1790, by striking out the word "WHITE," fixed the same standard of qualification for all; and, in fact, granted and guarantied "civil liberty" to all who possessed that qualification. Are we now to be told, that the Convention did not intend to include colored men, and that BENJAMIN

154 See generally Roy H. Akagi, The Pennsylvania Constitution of 1838, 48 PA. MAG. HIST. \& BIOGRAPHY 301, 317-19 (1924) (recounting debate in convention over disenfranchisement); Eric Ledell Smith, The End of Black Voting Rights in Pennsylvania: African Americans and the Pennsylvania Constitutional Convention of 1837-1838, 65 PA. HIST. 279 (1998) (describing background of disenfranchisement and Black protest).

155 Hobbs v. Fogg, 6 Watts 553, 559-60 (Pa. 1837) (holding that term "freeman" in the description of the electorate in Pennsylvania constitution could not mean freed slave, disregarding fact that constitutional convention had struck "white" out of the requirement). While the court may have been correct in its historical analysis of the word "freeman," see GOWDER, supra note 92, at 131-37 (describing the concept of the freeman, or liber homo, in English legal history), its refusal to acknowledge the far more natural interpretation of striking out the word "white" seems, at best, highly questionable. In fact, the court articulated a quite implausible theory for why the word "white" was removed: "it was feared that respectable men of dark complexion would often be insulted at the polls, by objections to their colour." Hobbs, 6 Watts at 559. Yet, of course, that result could not be avoided by removing the word "white" but retaining a racial qualification for suffrage, as a person "of dark complexion" could just as easily have been "insulted at the polls" by disputing their race. See generally Ariela J. Gross, What BLOOD WON'T TELL: A History OF RACE ON TRIAL IN AMERICA (2008) (recounting history of legal disputes over racial status and racial ambiguity). 
FRANKLIN did not know what he was about, forasmuch as it was impossible for a colored man to become a citizen of the commonwealth?

It may here be objected to us, that in point of fact we have lost by the recent decision of the Supreme Court, in the case of Fogg vs. Hobbs, whatever claim to the right of suffrage we may have had under the Constitution of 1790; and hence have no reason to oppose the amended Constitution. Not so. We hold our rights under the present Constitution none the cheaper for that decision. The section already cited gives us all that we ask - all that we can conceive it in the power of language to convey. Reject, fellow citizens, the partial, disfranchising Constitution offered you by the Reform Convention, and we shall confidently expect that the Supreme Court will do us the justice and itself the honor to retract its decision. Should it not, our appeal will still be open to the conscience and common sense of the people, who through their chief magistrate and a majority of two-thirds of both branches of the Legislature may make way to the bench of the Supreme Court, for expounders of the Constitution who will not do violence to its most sacred and fundamental principles. ${ }^{156}$

Note how, in that passage, Purvis relies on the belief in a genuine constitutional demos including Black Pennsylvanians, which had it in its power to take control of the rogue Supreme Court. This is just how I said above that the constitutional conception must respond to such judicial misbehavior. ${ }^{157}$

The Pennsylvania declaration in turn appealed to the Declaration of Independence and offered conditional allegiance only to the state it formed:

We lay hold of the principles which Pennsylvania asserted in the hour which tried men's souls - which BENJAMIN FRANKLIN and his eight colleagues, in the name of the commonwealth, pledged their lives, their fortunes, and their sacred honor to sustain. We take our stand upon that solemn declaration, that to protect inalienable rights "governments are instituted among men, deriving their JUST POWERS from the CONSENT of the governed," and proclaim that a government which tears away from us and our posterity the very power of CONSENT, is a tyrannical usurpation which we will never cease to oppose. We have seen with amazement and grief the apathy of white Pennsylvanians while the "Reform Convention" has been perpetrating this outrage upon the good old principles of Pennsylvania freedom. But however others may forsake these principles, we promise to maintain them on Pennsylvania soil, to the last man. If this disfranchisement is designed to uproot us, it shall fail. Pennsylvania's

156 Robert Purvis et Al., ApPeal of Forty Thousand Citizens, Threatened with DisenfRANChisement, TO THE PEOPLE OF PENNSYlvania 6-7 (1838), https://archive.org/ details/appealoffortytho00purv/page/n3 [https://perma.cc/W9LT-4ALU]. For the attribution of this document, see Nicholas Wood, "A Sacrifice on the Altar of Slavery": Doughface Politics and Black Disenfranchisement in Pennsylvania, 1837-1838, 31 J. EARLY RePUBLIC 75, 76 (2011).

157 See supra text accompanying notes $62-72$ for a discussion of "democratic frustrations." 
fields, vallies, mountains, and rivers; her canals, railroads, forests, and mines; her domestic altars, and her public, religious and benevolent institutions; her Penn and Franklin, her Rush, Rawle, Wistar, and Vaux; her consecrated past and her brilliant future, are as dear to us as they can be to you. Firm upon our old Pennsylvania BILL OF RIGHTS, and trusting in a God of Truth and Justice, we lay our claim before you, with the warning that no amendments of the present Constitution can compensate for the loss of its foundation principle of equal rights, nor for the conversion into enemies of 40,000 friends. ${ }^{158}$

Thus, faced with the threat of impending exclusion, the Black citizens of Pennsylvania laid a strong claim to co-citizenship with White Pennsylvanians, a community of interest as well as shared enterprise on the basis of the state constitution, as well as of the values described in the Declaration of Independence. ${ }^{159}$

\section{The Declaration of Independence as Prophecy}

It is worth taking a moment to specifically consider the constitutional status of the Declaration of Independence, which recurs frequently in this Part. The Declaration can be seen as a constitutional document for the reason given by legal scholar Jack Balkin: "The Declaration is our constitution. It is our constitution because it constitutes us, constitutes us as a people "conceived in liberty, and dedicated to a proposition." ${ }^{160}$ In other words, the Declaration stands in a similar relation to the American demos as the Constitution does, as a speech act that both claims to represent the American people and simultaneously creates it. We might say that our history contains two documentary assertions of constituent power on behalf of the American people - the power to declare itself a separate popular entity and the power to proclaim its fundamental law.

Reconstruction historian Eric Foner explains that Black Americans in the nineteenth century saw the Declaration as expressing the aspirations which the Constitution also expressed and then claimed to fill out. ${ }^{161}$ As W.E.B. Du Bois said, "[T] here are to-day no truer exponents of the pure human spirit of the Declaration of Independence than the American Negroes ....."162

158 PURVIS ET AL., supra note 156, at 18.

159 For instance, other parts of the document emphasized the fighting of Black Americans in the Revolutionary War and the payment of taxes by Black Pennsylvanians.

160 J.M. Balkin, The Declaration and the Promise of a Democratic Culture, 4 WIDENER L. SYMP. J. 167, 168 (1999); see also Alexander Tsesis, Self-Government and the Declaration of Independence, 97 CORNELl L. REV. 693 (2012) (discussing the legal significance of the Declaration).

161 Foner, supra note 79, at 873. Hartog notes that excluded groups claiming rights through American history have often focused on the Declaration. Hartog, supra note 153, at 1016-17.

162 W.E.B. Du BoIs, ThE Souls of Black FolK 14 (First Vintage Books ed. 1990). 
Abolitionist James McCune Smith, in 1843, cast these ideas in the language of destiny and purification. ${ }^{163}$ Arguing that the United States merely "simulate[s] a Republican form of Government," 164 he contrasts the position of Black Americans to those of the Jews in Egypt — the Jews had the destiny to leave Egypt to become free, while the Black American has the destiny to remain in America and create American freedom:

One law then, at least, we are by our position destined to exhibit; and that is that the enslaved should remain upon the soil, and amid the institutions which enthral them in order to bring liberty to the one by purifying the other. ${ }^{165}$

Like Purvis, Smith draws heavily on the Declaration of Independencewhich could serve as the genuine documentary instantiation of constitutional value unavailable to the Constitution itself because of the twisting of the latter to permit slavery. Thus, Smith contrasts the Constitution, a corrupted document, with the Declaration, a pure document, prophesying that the destiny of the Black American is to raise the former to meet the high standard of the latter:

This very doctrine is contained in the American Declaration of Independence, which declares "all men to have certain unalienable rights." But the Constitution of these United States, professedly constructed on the above principles, hold that there are some "other persons"- besides all men - who are not entitled to these rights. We are those "other persons"-we are the exception. It is our destiny to prove that even this exception is wrong, and therefore contrary to the highest interests of the whole people, and to eradicate from the Constitution this exception, so contrary to its general principles. ${ }^{166}$

He goes on to declare that to fulfill this destiny will be the salvation of the Republic as well. Importantly, he describes this salvation as "conservative," as merely achieving the claims that American government already makes.

What will be the result? Slavery must cease and over its grave there will grow up a pure Republic. The destiny then, which we must fulfill in relation to the form of government under which we dwell is eminently conservative. We will save the form of government and convert it into a substance. ${ }^{167}$

Smith can be seen as a forebear of a tradition of thought around Black destiny and American inclusion. Along these lines, theologian Sarah

163 James MCCune SMith, The Destiny of the People of Color (1843), in THE WORKS OF JAMES McCune SMith: Black InTELleCtual AND AbOLITIONIST 48 (John Stauffer ed., 2006).

$164 \mathrm{Id}$. at 50.

$165 \mathrm{Id}$. at 51.

$166 I d$. at 52.

${ }^{167} I d$. at 55. 
Azaransky characterizes the great civil rights lawyer and activist (and law professor, and poet, and priest) Pauli Murray's approach to the unfulfilled promise of American democracy as "democratic eschatology"-a theological approach to democratic inclusion that represents doctrine as "the conclusion of God's purposes, things yet to be seen, and, simply, things hoped for." 168 The purpose of eschatology, according to Azaransky, is to encourage Christians to build the Kingdom of the future (one cannot help but be reminded of Martin Luther King, Jr.'s "I may not get there with you"). ${ }^{169}$ The tradition of thought I describe in this Section-and indeed, Murray's own life as a civil rights lawyer-might be described as constitutional eschatology - as a belief in a latent purpose in America's founding ideals, paired with a commitment to bring about a kind of constitutional end of history in which those purposes are finally fulfilled.

Returning for a moment to the Declaration: it has continued its grip on Black American constitutional thought even to the present. Thus, political theorist Danielle Allen's discussion of her own relationship to the Declaration of Independence represents a look back at the history of Black Americans who have claimed the Declaration through their participation in collective action to secure the realization of its values and their own inclusion. ${ }^{170}$

In Professor Allen's words, "I claim the Declaration as patrimony"with the word "claim" doing the lion's share of work there, for, she goes on to explain, she is the descendant of a slave, and readers may for that reason look with skepticism on her claim: "Didn't the Declaration defend the liberty and equality only of white men of property?"171

She justifies her claiming not despite many of her ancestors not being within the group of people contemplated by its authors, but indirectly because of it. She cites her ancestors' active participation in a struggle for their own freedom - a grandfather's involvement in founding an NAACP chapter, her father's decision to leave the South to avoid the omnipresent prospect of Jim Crow violence, other ancestors' involvement in the

\footnotetext{
168 Sarah AZARANSKy, The Dream Is FreEdom: Pauli Murray and AMERICAN DEMOCRATIC FAITH 16 (2011).

169 Id. at 16-17. The reference in the text to King is from Martin Luther King, Jr., Address Delivered at Bishop Charles Mason Temple: I've Been to the Mountaintop (Apr. 3, 1968), https://kinginstitute.stanford.edu/king-papers/documents/ive-been-mountaintop-address-deliveredbishop-charles-mason-temple [https://perma.cc/F3JN-GDJL].

170 Danielle Allen, Our DeClaration: A REAding OF THE DEClaration of INDEPENDENCE IN DEFENSE OF EQUALITY 36-37 (2014).

${ }^{171} I d$. at 36.
} 
movement for women's suffrage - as reflecting their "wanting to be free"the same desire represented by the text of the Declaration. ${ }^{172}$

Summing up, she punctuates her claim to the Declaration as patrimony as follows: "Equality and freedom. Love of these ideas made my people."173 In other words, it is her ancestors who claimed the Declaration for her, through their attachment to the ideals it represented - even if the actual society that it stood for failed to meet those ideals - and through their active work to make that society more closely meet those ideals. Note also the fruitful ambiguity in the term "my people," which, it seems to me, can refer both to Black Americans and to the entire demos - and implicitly, to the idea that the Declaration and the love of freedom it reflects can unify those groups in a shared identity rooted in that common value.

This is a good place to note that while this sentiment has been most forcefully stated by Black Americans, as America's original class of internal excluded, it has also been articulated from a critical race standpoint more generally. Professor Mari Matsuda, speaking from her perspective as a Japanese-American, has expressed it in terms remarkably similar to Professor Allen's:

I can claim as my own the Constitution my father fought for at Anzio, the Constitution that I swore to uphold and defend when I was admitted to the bar. It was not written for me, but I can make it my own, using my chosen consciousness as a woman and person of color to give substance to those tantalizing words "equality" and "liberty." 174

\section{The Purified Constitution and the Continuing Need for Political Action}

Following the Civil War, as Professor Eric Foner has described, "the national Constitution took its place alongside the Declaration of Independence as a central reference point in black political discourse." 175 Smith's prophecy was partly fulfilled: the Constitution was purified of much of the taint of slavery, and so it could be permitted to stand on the same noble plane as the Declaration. From another angle: Douglass had been proven right that the Union could rein in the South and abolish slavery, the Thirteenth Amendment was quickly rammed through, and it became easier

\footnotetext{
${ }^{172} I d$.

173 Id. at 37.

174 Mari J. Matsuda, When the First Quail Calls: Multiple Consciousness as Jurisprudential Method, 11 WoMEN's RTS. L. ReP. 7, 10 (1989); see also Melvin L. Rogers, David Walker and the Political Power of the Appeal, 43 POL. THEORY 208 (2015) (reading David Walker's Appeal to the Colored Citizens of the World as a claim to citizenship on behalf of Black Americans on the basis of their capacity to participate in a shared project of self-government).

175 Foner, supra note 79 , at 880 .
} 
for those with less vision than Douglass to see the potential in the Constitution.

Other Black Americans promptly picked up some of Douglass's key points, particularly the claim that the Constitution had always contained in it the latent promise of inclusion, and paired it with the recognition that this promise must be actively seized by Black Americans. Thus, in 1865, the Black citizens of Norfolk, Virginia, formed a committee which issued a statement on their claims to suffrage by operation of law:

No sane person will for a moment contend that color or birth are recognized by the Constitution of the United States as any bar to the acquisition or enjoyment of citizenship. Further, the Congress of the Confederation expressly refused in June, 1778, to permit the insertion of the word "white" in the fourth article of Confederation, guaranteeing to the "free inhabitants" of each State, the privileges and immunities of citizens, in all the States. Free people of color were recognized voters in every State but South Carolina, at the time of the formation of the Constitution of the United States, and therefore clearly formed part of the "people" of the United States, who in the language of the preamble to the Constitution "ordained and established" that Constitution. It follows, then, that they are entitled to a full participation in all the benefits that Constitution was ordained to confer, and, among others, to the inestimable blessings of "a republican form of government," guaranteed to the people of each State, by Sec. 4th, Art. IV of the Constitution. ${ }^{176}$

In that passage, the Black citizens of Norfolk simultaneously claim authorship of the Constitution - as "recognized voters" at the time of ratification-and interpret it both to support their status as citizens and members of We the People - notably, prior to the Fourteenth and Fifteenth Amendments - and to entitle them to the right to vote. Shortly thereafter, they recognize that this right cannot be secured except by organized political action:

In conclusion, we wish to advise our colored brethren of the State and nation, that the settlement of this question is to a great extent dependent on them, and that supineness on their part will do as much to delay if not defeat the full recognition of their rights as the open opposition of avowed enemies. Then be up and active, and everywhere let associations be formed having for their object the agitation, discussion and enforcement of your claims to equality before the law, and equal rights of suffrage. Your opponents are active; be prepared, and organize to resist their efforts. We would further advise that all political associations of colored men, formed within the limits of the State of Virginia,

176 NORFOLK COMMITTEE OF COLORED CITIZENS, EQUAL SUFFRAGE: ADDRESS FROM THE COLORED Citizens OF Norfolk, VA., to the People OF the United States 5-6 (1865), https://www.loc.gov/item/09032794 [https://perma.cc/38YK-SV2K]. 
should communicate the fact of their existence, with the names and post office addresses of their officers, to Joseph T. Wilson, Norfolk, Va., in order that communication and friendly cooperation may be kept up between the different organizations, and facilities afforded for common and united State action, should occasion require it. ${ }^{177}$

The message concludes with a declaration of their allegiance to the United States: "We are Americans, we know no other country, we love the land of our birth and our fathers . . .."178

This retroactive reading continued into the turn of the century. In an 1899 speech decrying the growth of Jim Crow, author and activist Charles Chesnutt casts the Constitution as always having contained the seeds of racial equality and the Reconstruction Amendments as merely a clarification:

The Constitution of the United States proclaims in spirit if not in words, equality before the law. Before the Civil War this was construed to apply to white men, but the 13th, 14th, and 15th Amendments make it perfectly clear that it applies to all white and colored men born or naturalized in the United States. The white people of the South have declared, as they did once before to their sorrow, that they are superior to the Constitution, and that the Negro shall not vote. ${ }^{179}$

Yet Chesnutt, too, recognizes that this constitutional truth will be dead, even in the courts, without collective action. From a speech five years later:

Our Supreme Court, in passing upon the disenfranchisement cases to which I have referred, has said that the remedy for the conditions complained of in the South, is political rather than judicial. I do not follow the distinction. Political action can only result in the enactment of laws, which it is the province of Courts to enforce. I think what the Supreme Court means to say is that its function is to interpret and enforce the will of the people, and that it will not enforce a law which, though approved when made, has since become obnoxious. If this be true, then there remains but one method by which these wrongs can be righted - the creation of a wholesome public opinion which will demand political action. ${ }^{180}$

Chesnutt also adopted, following Douglass, the strategy of taking a broad and moralized interpretation of the Constitution. In a 1908 speech, he

177 Id. at 8

178 Id. at 9

179 CHARles W. ChesnutT, Liberty and the Franchise (1899), in CHARLES W. CHeSnUtT: EsSAYS AND SPEECHES 101, 106 (Joseph R. McElrath, Jr. et al. eds., 1999) [hereinafter CHESNUTT]; see also Charles W. ChesnutT, The Courts and the Negro (1908), in ChESNuTT (endorsing Justice Harlan's description of Dred Scott in the dissent in the Civil Rights Cases, where the latter alleges that Justice Taney "virtually inserted a new clause in the Constitution," and going on to describe it as a "narrow and strained interpretation of the law").

180 Charles W. Chesnutt, The Race Problem, in CheSnutT supra note 179, at 196, 201. 
notes that the Supreme Court interpreted the Reconstruction Amendments as "not intended to wipe out distinctions of race," but declares that (at least as to legal distinctions) "[i]f they were not they ought to have been, and we should plead for the larger interpretation; we should impress upon every court that it is a court of conscience as well as a court of law."'181

Fast-forwarding a few decades, King echoed this sentiment in his Letter from a Birmingham Jail, recognizing both that equal rights have been owed to Black Americans since the Founding and even before ("three hundred and forty years"), including under the Constitution, and yet that they cannot be acquired except through action:

We know through painful experience that freedom is never voluntarily given by the oppressor; it must be demanded by the oppressed. Frankly, I have never yet engaged in a direct action movement that was "well timed," according to the timetable of those who have not suffered unduly from the disease of segregation. For years now I have heard the words "Wait!" It rings in the ear of every Negro with a piercing familiarity. This "Wait" has almost always meant "Never." It has been a tranquilizing thalidomide, relieving the emotional stress for a moment, only to give birth to an ill-formed infant of frustration. We must come to see with the distinguished jurist of yesterday that "justice too long delayed is justice denied." We have waited for more than three hundred and forty years for our constitutional and God-given rights. ${ }^{182}$

\section{Conditional Attachment to the Constitution}

Let us for a moment return to Reconstruction. Congressman Joseph Rainey was a freedman who was the first Black American to serve in the House of Representatives. Speaking in 1871 in support of a bill to devote federal efforts to fighting Ku Klux Klan terrorism, Congressman Rainey nicely captured the idea of conditional allegiance. Should it achieve its highest values - which, he argues, it can, rightly interpreted - then it's worthy of respect. If it does not, then it is fit only to be abandoned and ignored. Rainey puts an "if" in front of Douglass: either the Constitution can be read as Douglass would have it be read, or it has no value at all.

I take the ground that, in my opinion, lies far above the interpretation put upon the provisions of the Constitution. I stand upon the broad plane of right; I look to the urgent, the importunate demands of the present emergency; and while I am far from advocating any step not in harmony with that sacred law of our land, while I would not violate the lightest word of that chart which has so well guided us in the past, yet I desire that so broad and liberal a construction be

181 Charles W. CheSnUtT, Rights and Duties (1908), in ChESNUtT supra note 179, at 252, 257.

182 See Martin Luther King, Jr., Letter from a Birmingham Jail, STANFORD U. (Apr. 16, 1963), available at http://okra.stanford.edu/transcription/document_images/undecided/630416-019.pdf [https://perma.cc/S5KU-T7WM]. 
placed upon its provisions as will insure protection to the humblest citizen, without regard to rank, creed, or color. Tell me nothing of a constitution which fails to shelter beneath its rightful power the people of a country!

I believe when the fathers of our country framed the Constitution they made the provisions so broad that the humblest, as well as the loftiest citizen, could be protected in his inalienable rights. It was designed to be, and is, the bulwark of freedom, and the strong tower of defense, against foreign invasion and domestic violence. I desire to direct your attention to what is imbodied in the preamble, and would observe that it was adopted after a liberal and protracted discussion on every article composing the great American Magna Charta. And like a keystone to an arch it made the work complete.... [Here, Rainey quotes the Preamble.]

If the Constitution which we uphold and support as the fundamental law of the United States is inadequate to afford security to life, liberty, and propertyif, I say, this inadequacy is proven, then its work is done, then it should no longer be recognized as the Magna Charta of a great and free people; the sooner it is set aside the better for the liberties of the nation. ${ }^{183}$

Douglass himself, a decade and a half later, expressed similar sentiments upon observing the betrayal of Reconstruction in the South. Even in the face of such treachery, he maintained his faith in the rights of the Constitution and the constitutional capacity of the government to act but noted that allegiance to that government is conditional on that action:

I know it is said that the general government is a government of limited powers. It was also once said that the national government could not coerce a state and it is generally said that this and that public measure is unconstitutional. But whenever an administration has bad [sic] the will to do anything, it has generally found Constitutional power to do it. If the general government had the power to make black men citizens, it has the power to protect them in that citizenship. If it had the right to make them voters it has the right to protect them in the exercise of the elective franchise. If it has this right, and refuses to exercise it, it is a traitor to the citizen. If it has not this right, it is destitute of the fundamental quality of a government and ought to be hissed and hurried out of the sisterhood of government, a usurper, a sham, a delusion and a snare.

On the other hand, if the fault is not in the structure of the government, but in the treachery and indifference of those who administer it, the American people owe it to themselves, owe it to the world, and to the Negro, to sweep from place and power those who are thus derelict in the discharge of their place

183 Cong. Globe, 42d Cong., 1st Sess. 394-95 (Apr. 1, 1871). 
in the government who will not enforce the Constitutional right of every class of American citizen. ${ }^{184}$

Douglass, like Purvis, wanted to believe that the fault is not in the Constitution but in the corrupt people who are called upon to administer and interpret it; the first strategy is to sweep them aside. If that fails-if the Constitution itself genuinely is corrupt at bottom, then it simply does not deserve attachment after all. ${ }^{185}$

This stance of conditional attachment persisted well into the late twentieth century. Jamaican-American poet and activist June Jordan's essay Break the Law! expresses the same stance toward the law in the abstract. ${ }^{186}$ She begins by praising the laws establishing desegregation:

I had forgotten. Or I had never understood: The hotel had been forced to desegregate, which meant the hotel had been forced to allow me to swim in that pool. And, in response, the hotel was daring me to go ahead: Get into that murky taboo cistern absolutely shunned, now, by white people.

They would boycott, they would forfeit, the summertime relief of swimming rather than mingle their white bodies in the same element that held my own.

Until I stood in that unnatural dark of that unnatural stillness by that pool, I had never felt white hatred so close, and everywhere, around me. Now I did. Now I knew.

This was not an attitude or a preference. This was shotgun-serious loathing of me and my kind.

The answer to that shotgun was the law.

You didn't have to like it. You didn't have to love me. But you did have to obey the law and let me swim.

184 Frederick Douglass, I Denounce the So-Called Emancipation as a Stupendous Fraud (Apr. 16, 1888), in DougLASS, supra note 131, at 711, 720.

185 Du Bois took a more cynical path to the same idea. In a passage in Black Reconstruction, he goes on a scornful excursus against "fetich-worship of the Constitution," and declares there is "[n]o more idiotic program" than to oblige it to be obeyed, at least if it were interpreted to forbid Reconstruction. Yet even in the midst of this outpouring of anti-Constitutionalism, he cannot help but endorse Douglass's interpretation of its original anti-slavery character! "Certainly, no one could argue ... that the Constitution was a pro-slavery document. Yet, unconstitutionally, the South made it a pro-slavery document ...." W. E. BURGHARDT DU BOIS, BLACK RECONSTRUCTION: AN ESSAY TOWARD A HISTORY of the Part Which Black Folk Played in the Attempt to ReConstruct Democracy iN AMERICA, 1860-1880, at 336-37 (Russell \& Russell 1963). Du Bois hardly accepts the Constitution here, but he at least seems to imply that his rejection of it springs from the fact that it has been misread to do things like permit slavery and forbid Reconstruction.

186 June Jordan, Break the Law!, in SOME OF Us Did Not DiE: New AND SElECTED EsSAYS OF JUNE JORDAN 55, 55-56 (2002). 
Without the law on my side, I damn straight could not have traveled from New York to Mississippi without horrible damage to my bladder, extreme dehydration, and a variety of humiliating messages imprinted on my soul. Without the law on my side, and after so long, I damn straight could not have stayed in a downtown Jackson hotel/motel or rented a car at the airport, or ordered a cup of coffee, anywhere, or exhibited the idiotic temerity of daring to think about doing anything anywhere that didn't say, COLORED.

That's the before and after story of the shotgun and the law. That's the before and after story of white hatred of Black folks. Before, they just hated us. After, they hated us or they didn't hate us, but we were moving, now, moving lawfully, see, into the same element that upheld their privileged white bodies. The same water and the same air and, sooner or later, the same classroom, and the same apartment building, and the same workplace, because we didn't have some kind of a dream about any of these things: We had the law equalizing our rights as American citizens. ${ }^{187}$

Thus far, so good, the law - and, indeed, the Constitution, as it is the Constitution that established the framework for desegregation and authorized Congress to legislate to push it further-stands as the sole defense for Black Americans against hate. But then Jordan turns to Proposition $209,{ }^{188}$ which amended California's Constitution to forbid affirmative action in 1996. There, she stands against the law and calls upon the Chancellor of the University of California to break it, to ensure the inclusion of Black students in the metaphorical pool of University of California students. ${ }^{189}$ Like Purvis, she invokes the constitutional People-very much including Black people - as the ultimate authority to rectify this unjust, and illegitimate, law. On behalf of We the People, she claims both the authority to reject a (state) constitution licensing the educational exclusion of Black Americans and the right to righteous lawbreaking in order to restore American constitutionalism to its rightful position as the protector of Black Americans:

It was once against the law for Blackfolks to swim in indoor, or outdoor, public waters.

We had to break those laws or agree to the slaveholder's image of us: three fifths of a human being.

\footnotetext{
187 Id.

188 Proposition 209 Prohibition Against Discrimination or Preferential Treatment by State and Other Public Entities, Legis. ANALYST's OFF. (Nov. 5, 1996), https://lao.ca.gov/ballot/1996/ prop209_11_1996.html [https://perma.cc/N3G2-NHL9].

${ }^{189} \mathrm{Id}$. at $56-58$.
} 
When the law is wrong, when the law produces and enjoins manifest and undue injury to a people, when the law punishes one people and privileges another, it is our moral obligation to break the law!

The law is not God-given!

2,100 minority students with straight-A, or better, grade point averages denied admission to U.C.-Berkeley?!

To the Chancellors of the entire University of California system I say: Break the law!

We, the people, we'll take it from there. ${ }^{190}$

\section{Cynical Faith and Democratic Identity}

The goal at which this tradition in Black American thought can be read to aim is a rebuilding of American popular identity. This is expressed in Langston Hughes's poem Let America Be America Again. ${ }^{191}$

The poem begins by juxtaposing the valorized self-image of America with reminders that this image has never been available to Black Americans:

Let America be America again.

Let it be the dream it used to be.

Let it be the pioneer on the plain

Seeking a home where he himself is free.

(America never was America to me. $)^{192}$

Yet, a few stanzas down, he claims, in solidarity with others who found themselves on America's shores, authorship of the American dream as a parallel to the way that Black bodies built its wealth:

Yet I'm the one who dreamt our basic dream

In the Old World while still a serf of kings,

Who dreamt a dream so strong, so brave, so true,

That even yet its mighty daring sings

In every brick and stone, in every furrow turned

That's made America the land it has become.

$\mathrm{O}, \mathrm{I}$ 'm the man who sailed those early seas

In search of what I meant to be my home -

For I'm the one who left dark Ireland's shore,

And Poland's plain, and England's grassy lea,

190 Id. at 58

191 Langston Hughes, The Collected Poems of Langston Hughes 189-91 (Arnold Rampersad \& David Roessel eds., 1994).

192 Id. at 189. 
And torn from Black Africa's strand I came

To build a "homeland of the free." 193

That heritage, he claims a few more stanzas down, gives him a right to build the real America, the America that fulfills its promise of freedom:

O, yes,

I say it plain,

America never was America to me,

And yet I swear this oath -

America will be! ${ }^{194}$

Novelist, essayist, and activist James Baldwin similarly describes the "act of faith" that is represented by demanding Americans live up to their own values and explains that it has the capacity to constitute, or reconstitute, the American We the People which never properly existed:

This is not very different from the act of faith demanded by all those marches and petitions while Martin was still alive. One could scarcely be deluded by Americans anymore, one scarcely dared expect anything from the great, vast, blank generality; and yet one was compelled to demand of Americans - and for their sakes, after all - a generosity, a clarity, and a nobility which they did not dream of demanding of themselves. Part of the error was irreducible, in that the marchers and petitioners were forced to suppose the existence of an entity which, when the chips were down, could not be located-i.e., there are no American people yet: but to this speculation (or desperate hope) we shall presently return. ${ }^{195}$

As promised, he later fills out the notion of bringing into being the American people, expressing it as a kind of inclusive confrontation, forged in social action:

The black and white confrontation, whether it be hostile, as in the cities and the labor unions, or with the intention of forming a common front and creating the foundations of a new society, as with the students and the radicals, is obviously crucial, containing the shape of the American future and the only potential of a

${ }^{193}$ Id. at 190-91. Cf. Frederick Douglass, The Free Negro's Place Is in America, Speech Delivered at National Convention of Liberty Party, Buffalo, New York (Sept. 18, 1851), in DoUgLASS, supra note 131, at 176-77 ("I believe that simultaneously with the landing of the Pilgrims, there landed slaves on the shores of this continent, and that for two hundred and thirty years and more we have had a foothold on this continent. We have grown up with you; we have watered your soil with our tears; nourished it with our blood, tilled it with our hard hands. Why should we not stay here? We came when it was a wilderness, and were the pioneers of civilization on this continent. We levelled your forests; our hands removed the stumps from your fields, and raised the first crops and brought the first produce to your tables. We have been with you, are still with you, have been with you in adversity, and by the help of God will be with you in prosperity.").

194 HugHES, supra note 191, at 191.

195 JAMES BALDWIN, No NAME IN THE STREET 10 (First Vintage Int'l ed. 2007). 
truly valid American identity. No one knows precisely how identities are forged, but it is safe to say that identities are not invented: an identity would seem to be arrived at by the way in which the person faces and uses his experience. It is a long drawn-out and somewhat bewildering and awkward process. ${ }^{196}$

Professor Turner finds similar ideas in the work of Ralph Ellison, arguing that Ellison's work called for the creation of a shared American identity incorporating Black Americans, one that offers a new, democratic identity to both White and Black citizens. This identity requires that Whites be educated in the injustice of their society. ${ }^{197}$

For Baldwin, this rebuilding comes from the love of Black Americans for a society of which they understand themselves as members, despite persistent exclusion:

To be an Afro-American, or an American black, is to be in the situation, intolerably exaggerated, of all those who have ever found themselves part of a civilization which they could in no wise honorably defend - which they were compelled, indeed, endlessly to attack and condemn — and who yet spoke out of the most passionate love, hoping to make the kingdom new, to make it honorable and worthy of life. Whoever is part of whatever civilization helplessly loves some aspects of it, and some of the people in it. A person does not lightly elect to oppose his society. One would much rather be at home among one's compatriots than be mocked and detested by them. And there is a level on which the mockery of the people, even their hatred, is moving because it is so blind: it is terrible to watch people cling to their captivity and insist on their own destruction. I think black people have always felt this about America, and Americans, and have always seen, spinning above the thoughtless American head, the shape of the wrath to come. ${ }^{198}$

What clearer explication can there be of cynical faith? In essence, it is to hold out hope in the possibility of rebuilding, while seeing the doom and destruction looming over the broken, never achieved, yet paradoxically beloved demos. ${ }^{199}$

This cynical faith remains today and has been forcefully articulated by one of the founders of Critical Race Studies. Professor Patricia Williams has

\footnotetext{
196 Id. at 189.

197 Turner, supra note 76, at 668-70.

198 BALDWIN, supra note 195, at 194.

199 Note also the double-identity that Baldwin assumes, simultaneously describing Black Americans as "part of [American] civilization," yet at the same time adopting an outsider perspective from which they can see the doom which Americans are "thoughtless" about - the same insider-outsider perspective Douglass adopts. See supra note 122 and accompanying text.
} 
given us the most eloquent modern articulation of that faith and its capacity to serve as a creative force in constitutional rebuilding:

To say that blacks never fully believed in rights is true; yet it is also true that blacks believed in them so much and so hard that we gave them life where there was none before. We held onto them, put the hope of them into our wombs, and mothered them - not just the notion of them. We nurtured rights and gave rights life. And this was not the dry process of reification, from which life is drained and reality fades as the cement of conceptual determinism hardens round-but its opposite. This was the resurrection of life from 400-year-old ashes; the parthenogenesis of unfertilized hope. ${ }^{200}$

Professor Williams further explains the dependency of this kind of faith on the possibility of finding its warrant in ideas that are actually present in one's constitutional institutions:

But if it took this long to breathe life into a form whose shape had already been forged by society and which is therefore idealistically if not ideologically accessible, imagine how long would be the struggle without even that sense of definition, without the power of that familiar vision. What hope would there be if the assignment were to pour hope into a timeless, formless futurism? ${ }^{201}$

The task of the activist, in her terms, is to first "unmask the sorcerer"reveal the fraudulent claims of existing social institutions - but then "the mask had to be donned by the acquiring shaman, and put to good ends" to force them into their true and worthy form. ${ }^{202}$

Williams herself does not name this approach "faith." I take that label for Williams's account from Professors Derrick Bell and Preeta Bansal, who describe both Williams's articulation and, implicitly, Douglass's as follows: "Recognizing that constitutional rights have never translated into literal mandate for white leaders responding to black demands for equality, blacks nevertheless have clung to the Constitution as an embodiment of the ideals of freedom and equality for all ...."203

Bell and Bansal interpret Williams in the context of commenting on Professor Michelman. Ultimately, they reluctantly and skeptically endorse Michelman's version of the constitutional conception, but only as a matter of faith. Indeed, they read Michelman to share this cynical faith, and to be willing "like generations of black Americans ... to sift through the ashes of

\footnotetext{
200 Patricia J. Williams, Alchemical Notes: Reconstructing Ideals from Deconstructed Rights, 22 HARV. C.R.-C.L L. REV. 401, 430 (1987).

${ }^{201} I$ d.

202 Id. at 431-32.

203 Derrick Bell \& Preeta Bansal, The Republican Revival and Racial Politics, 97 YALE L.J. 1609, 1619 (1988). Bell describes this general faith in justice among Black activists elsewhere. DERRICK BELL, Faces at the Bottom of the Well: The Permanence of Racism, at xiii-xiv (1992).
} 
our political and jurisprudential past for remnants of what might have been and, in his view, what might yet be." ${ }^{204}$ Bell and Bansal also argue, as I have in this Article, that the constitutional conception must fail if Black Americans are not included - that, "the oppression of blacks does not oppress blacks alone, but, indeed,... it denies all of humanity the full emancipatory potential of critical, dialogic self-rule." ${ }^{205}$

Professor Dorothy Roberts has further explored the "cynical" side of cynical faith, offering as an example of "cynical legalism" "the Black Panthers' practice of surrounding police while they arrested a black man, demanding, law books in hand, that the 'pigs' abide by the letter of the law." ${ }^{206}$ This is cynicism, Roberts suggests, for the same reason that Black constitutional fidelity can be cynical — because the Panthers knew that the pigs would not actually follow the law.

We might say the same about Douglass - he knew that the slaveocracy would not follow the Constitution, at least not until they were forced to do so at gunpoint. The Panthers, of course, carried guns too. In one hand, the claim of Constitutional rights; in the other, the desperate resort to force. ${ }^{207}$

Professor Roberts denies that faith is the appropriate way to describe this stance toward the U.S. Constitution, characterizing it instead as a "faithfulness" that is cashed out "by relentlessly demanding that its interpretation live up to its highest principles and follow its strictest requirements." ${ }^{208}$ Here, I disagree with Professor Roberts. Why did the Panthers wield their law books in addition to their guns, if they did not hold out some faith, or at least hope, that the former had some force?

Professor Mari Matsuda has identified this dual stance toward law as a feature of outsider jurisprudence, more generally, and as an instance of $\mathrm{Du}$ Bois-like double consciousness - the capacity both to recognize the meaning of the law and its corruption. She highlights the courtroom self-defense of Angela Davis as its highest practical instantiation:

\footnotetext{
204 Bell \& Bansal, supra note 203, at 1620.

205 Id.

206 Dorothy E. Roberts, The Meaning of Blacks' Fidelity to the Constitution, 65 FordHAM L. REV. 1761, 1768 (1997).

207 Malcolm X at least once made a similar suggestion to a Cleveland audience in 1964-that violent resistance was acceptable for Black Americans when specifically paired with a confident claim of legal right:

Any time you know you're within the law, within your legal rights, within your moral rights, in accord with justice, then die for what you believe in. But don't die alone. Let your dying be reciprocal. This is what is meant by equality. What is good for the goose is good for the gander.

BROMEl, supra note 130, at 122-23 (quoting MALCOLM X, The Ballot or the Bullet, in MALCOLM X SPEAKS: SELECTED SPEECHES AND STATEMENTS 23, 34 (George Brietman ed., 1965)).

208 Roberts, supra note 206, at 1768.
} 
There are times to stand outside the courtroom door and say "this procedure is a farce, the legal system is corrupt, justice will never prevail in this land as long as privilege rules in the courtroom." There are times to stand inside the courtroom and say "this is a nation of laws, laws recognizing fundamental values of rights, equality and personhood." Sometimes, as Angela Davis did, there is a need to make both speeches in one day. Is that crazy? Inconsistent? Not to Professor Davis, a Black woman on trial for her life in racist America. It made perfect sense to her, and to the twelve jurors good and true who heard her when she said "your government lies, but your law is above such lies."209

Pauli Murray captures this double consciousness in a stanza in her famous poem Dark Testament and ascribes it to the country itself, conscious both of its highest aspirations and its cruelest injustices:

This is our portion, this is our testament,

This is America, dual-brained creature,

One hand thrusting us out to the stars,

One hand shoving us down in the gutter.

Put it all down in a time capsule,

Bury it deep in the soil of Virginia,

Bury slave-song with the Constitution,

Bury it in that vineyard of planters

And poll-taxers, sharecroppers and Presidents.

In coffin and outhouse all men are equal,

And the same red earth is fed

By the white bones of Tom Jefferson

And the white bones of Nat Turner. ${ }^{210}$

209 Matsuda, supra note 174, at 8; see also Mari J. Matsuda, Looking to the Bottom: Critical Legal Studies and Reparations, 22 HARV. C.R.-C.L. L. REV. 323, 334-35 (1987) (further discussing the Douglass tradition of constitutional interpretation and how it was reflected in King's later work). This dual consciousness may be a characteristic feature of contemporary critical race theory. See Angela P. Harris, Forward: The Jurisprudence of Reconstruction, 82 CALIF. L. REV. 741, 743 (1994) (characterizing the enterprise of critical race theory as combining a critical approach to American law with a "vision of liberation," a dynamic tension between "radical critique and racial emancipation"); see also Nick Bromell, A "Voice from the Enslaved": The Origins of Frederick Douglass's Political Philosophy of Democracy, 23 AM. LITERARY HisT. 697, 711 (2011) (suggesting that "the ability to manage contraries" is "a hallmark ... of the African-American tradition of political thought" and arguing that Douglass's constitutional theory is an example of this ability).

210 Pauli Murray, Dark Testament And Other PoEms 24-25 (1970). Nat Turner was the leader of a dramatic (and bloody) 1831 slave rebellion in Virginia. See generally Justin Fornal, Nat Turner's Slave Uprising Left Complex Legacy, NAT'L GEOGRAPHIC (Oct. 5, 2016), https://news. nationalgeographic.com/2016/10/nat-turner-slave-rebellion-legacy [https://perma.cc/6ZDV-VMZH]. I read the association between slave-song and the Constitution and between Jefferson and Turner to be a suggestion that slave rebellion was part of the tradition of the American Revolution. $C f$. FREDERICK DOUGLASS, LIFE AND TIMES OF FREDERICK DOUGLASS 129-130 (1882) ("The morality of free society 
This cynical faith seems to me to be the natural attitude of those engaged in claimant critique. Exclusion from the social order being critiqued gives the critic fair grounds for cynicism. At the same time, the aspiration to do something akin to internal critique, and the commitment to bring it about with collective action, to stand in the place of a participant in the scheme of value articulated by that social order, presupposes a kind of faith in that scheme of value. ${ }^{211}$

Williams fills out part of the basis for this faith in terms that harken to Douglass as well as to the constitutional patriots: because the Constitution offers itself up as a suitable place for these ambitions to be projected, "there is the spirit of the law, the symbology of freedom, which is in some ways utterly meaningless and empty-although at the same time this very emptiness provides a vessel to be filled with a sense of possibility, with a plurality of autonomous yearnings." 212

Ultimately, Williams, like Baldwin, understands the experience of rights-claiming for Black Americans as the development of a social identity as well as a fully integrated individual identity:

Blacks, however, may symbolize the King Lear who was pushed to the point of madness, who did not find his essential humanity while retaining some reference point to an identity as social being temporarily lost in the wilderness, but who ultimately lost everything, including a sense of self. The black slave experience was that of lost languages, cultures, tribal ties, kinship bonds, and even of the power to procreate in the image of oneself and not that of an alien master. That sort of confrontation with the utter powerlessness of status which is the true and full condition of the wilderness is what ultimately drove King Lear from insight into madness. Reduced to the basic provisions of food, water and a straw pallet, kings may gain new, perhaps profound, insight into those needs they share with all humankind. For others, however-for slaves, sharecroppers, prisoners and mental patients - the experience of poverty and need is fraught with the realization that they are dependent "on the uncertain and fitful protection of a world conscience" which has forgotten them as individuals, a collective mind which considers them (if it considers them at all)

could have no application to slave society. Slaveholders made it almost impossible for the slave to commit any crime, known either to the laws of God or to the laws of man. If he stole, he but took his own; if he killed his master, he only imitated the heroes of the revolution.").

211 Professor Bromell casts a similar idea in religious tones, suggesting that Martin Luther King, Jr. and Malcolm X had a (religious) "faith-as-tension [which] was caused by a conflict between their belief that a moral order had conferred this meaning on black suffering and would ultimately end it, and their very strong doubts that any moral order worthy of the name would have permitted such suffering in the first place." BROMELL, supra note 130, at 124. Swap out a religious "moral order" for a secular "constitution" and you have cynical faith in the legalistic context.

212 Patricia J. Williams, Commercial Rights and Constitutional Wrongs, 49 MD. L. REv. 293, 294 (1990). 
"examples of the universal abstraction Man." For the historically disempowered, the conferring of rights is symbolic of all the denied aspects of humanity: rights imply a respect which places one within the referential range of self and others, which elevates one's status from human body to social being. For blacks, then, the attainment of rights signifies the due, the respectful behavior, the collective responsibility properly owed by a society to one of its own. ${ }^{213}$

Williams moreover, in her discussion of the Black experience with claiming rights to inclusion, quotes a passage from French philosopher Paul Ricœur about how "human deeds are also waiting for fresh interpretations which decide their meaning" and "opened to this kind of practical interpretation through present praxis." ${ }^{214}$ I read her to mean that this kind of rights-claiming as action can be retroactively incorporated into the Constitution itself through something like Professor Benhabib's jurisgenerative politics. That is, because of the results of Black collective action, the claimed rights are inserted back into the will of a collective sovereign interpreting its own constitutional institutions. Black collective rights-claiming reaches back through history and changes the Constitution. In Douglass's words: "If the South has made the Constitution bend to the purposes of slavery, let the North now make that instrument bend to the cause of freedom and justice." 215

Going further, Williams, this time via a quote from Carl Jung, analogizes the incorporation of Black Americans into White society with an explicitly retroactive characterization of the integration of an individual identity:

Conscious realization or the bringing together of the scattered parts is in one sense an act of the ego's will, but in another sense it is a spontaneous manifestation of the self, which was always there. Individuation appears, on the one hand, as the synthesis of a new unity which previously consisted of scattered particles, and on the other hand, as the revelation of something which existed before the ego and is in fact its father or creator and is also its totality. ${ }^{216}$

\footnotetext{
213 Williams, supra note 200 , at $415-16$.

${ }^{214} I d$. at 426 (quoting Paul Ricœur, HeRMENEUTICS AND THE HUMAN SCIENCES: ESSAYS ON LANGUAGE, ACTION AND INTERPRETATION 208 (John B. Thompson ed. \& trans., 1981)).

215 Douglass, The Constitution of the United States, supra note 132, at 389.

216 Williams, supra note 200, at 429-30 (quoting CARL JUNG, Transformation Symbolism in the Mass, in Psyche And Symbol: A SELECtion from the Writings of C.G. Jung 148, 214 (Violet S. de Laszlo ed., 1958)). I think that the two concepts of double-consciousness and of fractured identity as a product of constitutional and democratic exclusion are particularly important ideas that are intellectually reachable only from the standpoint of the socially subordinated. Balkin analyzes Douglass's constitutional abolitionism as a key example in his own theory of constitutional redemption. JACK Balkin, Constitutional Redemption: Political Faith in an Unjust World 47, 112-13, 122-23
} 
Thus, finally, in Williams, we see a full integration of the stance toward the Constitution that I have drawn out in this Section. Black Americans, by collectively laying claim to the rights latent in the Constitution, can reveal and retroactively bring into being the People that make the Constitution real. Through a kind of Hegelian historical learning process, the American people comes to realize its own freedom. ${ }^{217}$ The Constitution-giving We the People plays the role of Spirit in this Hegelian comparison and is paradoxically both actual and actualizing. Actual, because the purported people articulated the constitutional values that provide the germ of their proper realization, and actualizing, because it requires action on the basis of Black claims to membership before the demos can truly come into being.

Let us pause here to bring the discussion back to the previous Part. Professor Habermas has argued that a constitution can serve as the basis for a project of cross-generational social learning which allows us to avoid the dilemma of constituent power by treating the constitution as simultaneously

(2011). At a high level, the argument in this Article is greatly in accord with Balkin's. But what Balkin misses, it seems to me, is just this combination of double consciousness and identity fracture in both the polity and in the individual. Reading Douglass with double consciousness in mind allows us to see that his words do not merely represent faith in the abolitionist reading of the Constitution, nor do they merely represent political rhetoric - and they do not even represent a simple conjunction of the two, in which his rhetoric was informed by faith in the potential truth of his words. I think for Douglass there was a genuine contradiction between the idea of the American Constitution and the practice of American constitutionalism, and a contradiction he took fully on board - he could understand the Constitution as legitimate and illegitimate, as representing values worth striving for and the betrayal of those values, just as in his Fourth of July speech, as discussed supra note 131, he simultaneously represented himself as citizen and non-citizen. The contradictions in Douglass's own identity as citizen and non-citizen reflect the contradictions in the identity of the demos which claimed authority over Douglass but denied that he was a member of it. These contradictions are the consequence of the fact that the social and legal world in which Douglass, and all Black Americans, have been embedded has sent these mixed messages - the institutional basis for understanding Black Americans as included and as excluded were always both available.

Thus, it was not simply the case that the Constitution had been used to do evil things, but that faith in the democratic process and in the human capacity to achieve the values that the Constitution expresses allowed someone in Douglass's position to see it as legitimate. Rather, there is a degree of constitutional evil beyond which the Constitution does not even exist in a coherent sense because a Constitution that denies its own demos lacks authority in the first place. There was, as Baldwin, supra note 195, suggested, no such thing as an American people, and hence no Constitution for them to have made; the only way to even believe in such a thing as an American Constitution at all, as a Black American in 1860, would be to identify a state of affairs, even if that state of affairs had to be located in the future, in which one could say that the Constitution was genuinely established under the authority of a demos including Black people. Yet at the same time, the Constitution did exist, and the American people did exist- the institutions that enslaved Douglass were not just imaginary. The only way to make any sense of it at all is to be able to live with the paradox and strive for the solution - the reconstitution of the demos - that resolves it.

217 See generally Daniel Little, Philosophy of History, in STANFORD ENCYCLOPEDIA OF PHILOSOPHY (Edward Zalta ed., Summer 2017), https://plato.stanford.edu/archives/sum2017/entries/history [https://perma.cc/4JVK-9V6M] (describing Hegel's philosophy of history as the self-discovery of human freedom). 
an ongoing product of and producer of the demos..$^{218}$ In slightly different forms, this is the idea that Professors Benhabib and Michelman have described as a "jurisgenerative" capacity. ${ }^{219}$ However, I have argued that constitutions lack this jurisgenerative capacity to the extent they are characterized by persistent illegitimate exclusion. For that reason, the American Constitution in particular cannot fulfill the law-legitimating and demos-creating ambitions of the constitutional conception.

And that's where Douglass and his intellectual heirs come in. Black Americans can, and have, participated in the ongoing production of the American Constitution despite the best efforts of the forces of white supremacy. If the demos ever becomes whole-if it ever fully includes Black Americans (and the others who have been unjustly excluded) - that inclusion will be a product of the efforts of Black (and other) activists who have demanded over centuries that America live up to the value claims its founding documents have made. Should that happy day ever come, we will be able to genuinely say that the Constitution and the now-completed demos have co-created one another, and the Constitution will, finally, be legitimate.

\section{A Note in Defense of the Ever-Living Now}

It might be objected that Douglass's constitutional reading, and my conception of wrongful exclusion, are ahistorical. Worse, to a historian, all this talk about retroactive revision of the demos and Hegelian anachronism might be rather alarming. After all, one might argue, those who were included in the eighteenth century, apart from abolitionists, thought that the exclusion of slaves (and women, and Native Americans) was consistent with popular sovereignty as they understood it. So while I may be able to say that exclusion was wrong in an absolute moral sense, obviously, and also wrong from the standpoint of the enslaved, can I really say that the United States lacked popular sovereignty from the standpoint of white men?220 Similarly, can Douglass really dismiss the originalist reading of the constitution as a legislative act? Why not just say that we ought to amend the Constitution going forward-either through Article Five or through Ackermanian nontextual interpretation-while acknowledging its legitimacy from the standpoint of the (White) generations who framed it in the past?

That is, if the United States did not lack popular sovereignty from the standpoint of White men, then we can perhaps represent the United States as a democracy that simply happened to engage in some human rights

\footnotetext{
218 See Habermas, supra note 35, at 774-75.

219 See BENHABIB, supra note 122, at 181; Michelman, supra note 122, at 1502.

${ }^{220}$ I thank Sarah Seo for raising this worry.
} 
violations with respect to foreigners (representing both Native Americans and enslaved people from Africa, as well as their descendants, as foreigners). On that conception, the United States at the Founding was an evil democracy, to be sure, but no less a democracy — and its treatment of slaves might be analogous to the Athenian genocide in Melos that Thucydides recountsterrible, but not inconsistent with popular sovereignty of the wrongdoer. ${ }^{221}$ On that reading, perhaps the United States did not violate its constitutional commitments, from the start, it is just that those commitments came to change over time.

I reject such a reading of Constitutional history. On the contrary, I claim that even the included, indeed, even the evildoers, at least sometimes recognized the fundamental incompatibility between slavery and the ideals of the Constitution. Consider the following, from a speech of Alexander Stephens, the Vice President of the Confederacy:

The new Constitution has put at rest forever all the agitating questions relating to our peculiar institutions-African slavery as it exists among us - the proper status of the $[\mathrm{N}]$ egro in our form of civilization. This was the immediate cause of the late rupture and present revolution. Jefferson, in his forecast, had anticipated this as the 'rock upon which the old union would split.' He was right. What was conjecture with him is now a realized fact. But whether he fully comprehended the great truth upon which that rock stood and stands may be doubted. The prevailing ideas entertained by him and most of the leading statesmen at the time of the formation of the old Constitution, were that the enslavement of the African was in violation of the laws of nature; that it was wrong in principle, socially, morally and politically. It was an evil they knew not well how to deal with, but the general opinion of the men of that day was, that somehow or other, in the order of Providence, the institution would be evanescent and pass away.... Those ideas, however, were fundamentally wrong. They rested upon the assumption of the equality of races. This was an error. It was a sandy foundation, and the idea of a government built upon it; when the 'storm came and the winds blew, it fell.' Our new government is founded upon exactly the opposite idea; its foundations are laid, its corner-stone rests upon the great truth that the Negro is not equal to the white man. That slavery-subordination to the superior race-is his natural and normal

221 ThuCydides, THE LANDMARK THuCydides: A COMPREHENSIVE GuIDE TO THE PELOPONNESIAN WAR 350-57 (Robert B. Strassler ed., rev. 1996) (describing Athenian genocide in Melos). Even on this account, it seems hard to say what to do with the exclusion of women, but at least women were not at the time subjected to genocide or enslavement like Native Americans and Black Americans (for whatever small comfort that may offer). 
condition. This, our new government, is the first in the history of the world, based upon this great physical and moral truth. ${ }^{222}$

If even a Confederate leader can understand the Constitution (of the Union) as rooted in "the assumption of the equality of the races," then how can that Constitution be read to permit the subordination of Black Americans from the get-go, except in terms of illegitimate hypocrisy?223

Even if it is ahistorical, a kind of ahistorical approach is, I'll submit, the right way to read the Constitution. Let's take Professors Ackerman, Benhabib, and Habermas seriously, and suppose that the Constitution can extend across time and have its meaning developed across generations. Then Professor Williams's conception of the demos, and those of Baldwin and Douglass, count just as much as the conception of the people who happened to be around at the end of the eighteenth century, for each generation has its part in developing the shared cross-generational constitutional identity. Jurisgenerative politics has to be at least a little bit retroactive.

Douglass himself expressed the spirit of this intergenerational conversation and the project of describing the bounds of We the People without deference to its historical exclusions in his Fourth of July speech. Rejecting the notion that the American people of his generation could rest on the heroic laurels of the founders who won their freedom from George III, he declared:

My business, if I have any here to-day, is with the present. The accepted time with God and His cause is the ever-living now .... We have to do with the past only as we can make it useful to the present and to the future. To all inspiring motives, to noble deeds which can be gained from the past, we are welcome. But now is the time, the important time. Your fathers have lived, died, and have done their work, and have done much of it well. You live and must die, and you must do your work. You have no right to enjoy a child's share in the labor of your fathers, unless your children are to be blest by your labors. ${ }^{224}$

These words apply just as well to constitutional theory. It is our interpretive labors which give meaning to the constitutional tradition handed down from prior generations. Every day we are obliged to ask whether American constitutional institutions are legitimate now? If not, can we justify an attachment to them based on the prospect of making them legitimate in

\footnotetext{
222 Du Bois, supra note 185, at 49-50 (citing Lucy Shelton Stewart, THE Reward of PATRIOTISM 41-42 (1930)) (emphasis omitted).

223 Relatedly, Professor Wilson J. Moses credits Douglass with the view, "common to his generation," that Jefferson was an abolitionist but that the cotton gin undermined the progress of this view. Wilson J. Moses, "The Ever-Present Now": Frederick Douglass's Pragmatic Constitutionalism, 99 J. AFR. AM. Hist. 71, 82 (2014).

${ }^{224}$ Douglass, The Meaning of July Fourth for the Negro, supra note 131, at 193.
} 
the future? The founding can help us answer those questions only insofar as the people who have a right to ask them, right here and now, share some affinity with the people of 1788 such that their choices ought to be meaningful to us. Thus, the Us of now, the We the People who today collectively recognize one another as the constituency of the Constitutionor who aspire to do so and aspire to be so recognized - must seek that affinity as we define ourselves, not as the founders would have defined us.

\section{CONCLUSION: BLACK CONSTITUTIONAL PATRIOTISM: "CHANGE THE JOKE AND SLIP THE YOKE"}

The line of thought stretching from Douglass to Williams can redeem the constitutional conception by illustrating the capacity of a constitution to be a resource even in conditions of persistent exclusion.

One of the consistent themes of the Douglass line of thought is that the Constitution can be claimed through action and through, as Allen says, love of the fundamental values of freedom and equality. This is something that Black Americans have been doing for a very long time. Consider the 180,000 Black Americans who served in the Union Army in the Civil War, and how they were instrumental in the victory that led to the Reconstruction Amendments. ${ }^{225}$ This act of claiming was also an act of authorship, partly on the basis of an attachment to the ideas written into America's Founding documents. That act of authorship fits nicely into the constitutional conception: the blood of Black Civil War soldiers, the sweat of Black civil rights activists, the tears of \#BlackLivesMatter activists, all have come attached to an appeal to foundational American values and to the Constitution that declares them. These acts are forms of participation in the intergenerational conversation described by Professors Habermas and Ackerman.

The only reason those acts of Black American authorship cannot currently serve as elements in a triumphalist story of jurisgenerative politics - in which Black Americans secured their own inclusion, and, with it, the legitimacy of the American constitution - is that they were betrayed. The authorial acts of the Civil War and Reconstruction and the Civil Rights Movement did not fully transform the Constitution, due to the unwillingness of White Americans to participate in the project of rebuilding We the People. The act of building a genuinely shared demos requires participation from the community as a whole, but rather than accept the invitation issued by these acts of authorship to join in co-creating a Constitution properly built on the ideals expressed by the Founders, White Americans responded with Klan

225 This figure comes from Foner, supra note 79, at 864. 
terror and Jim Crow and mass incarceration. To be sure, there were moments of cross-racial solidarity - for example, the election of Barack Obama as the nation's first Black president must have at least symbolic importance, for he needed to win many votes from non-Black Americans to get there. But then the pattern of backlash repeated, as he was replaced by the man who spread a conspiracy theory about Obama being born in Kenya ${ }^{226}$ and took out full page New York Times advertisements to kick off calls for the execution of five innocent Black men in New York City ${ }^{227}$ - a replacement facilitated by voter suppression which was permitted by the Supreme Court's evisceration of the signature legislative achievement of the Civil Rights Movement. ${ }^{228}$ The rebuilding of the demos just never seems to stick.

Professor Charles R. Lawrence III has explained how even this cycle of repeated gain and backlash can be integrated into the building of a movement, and, with it, a demos:

When people's movements successfully challenge and disrupt racist structures and institutions, and contest the narratives of racial subordination, the plunderers will respond with new law. The new laws will inflict new forms of violence and compose new narratives to make the new violence seem just. This does not mean that there is never progress, that the people's movements have not achieved real transformation. The transmutation of transformative change into re-enactment of subordination through quasi-reform is a constant threat. Those who would judge race reform law must recognize when law affirmatively moves society toward transformation and when it resists transformation by inflicting new forms of violence and justificatory narratives. The importance of race reform law is found not so much in the rights guaranteed and enforced by

226 Domenico Montanaro, Without Apology, Trump Now Says: 'Obama Was Born In' the U.S., NPR (Sept. 16, 2016), https://www.npr.org/2016/09/16/494231757/without-apology-trump-now-says-obamawas-born-in-the-u-s [https://perma.cc/V8HD-5V7A]; Donald J. Trump (@realDonaldTrump), TwITTER (May 18, 2012, 12:31 PM), https://twitter.com/realdonaldtrump/status/203568571148800001?lang=en [https://perma.cc/PY5Q-NCRE] ("Let's take a closer look at that birth certificate. @BarackObama was described in 2003 as being 'born in Kenya."'); see also Katie Rogers and Nicholas Fandos, Trump Tells Congresswomen to "Go Back" to the Countries They Came From, N.Y. Times (July 14, 2019), https://www.nytimes.com/2019/07/14/us/politics/trump-twitter-squad-congress.html

[https://perma.cc/M5M2-LSSQ] (recounting events where President suggested that group of Congresswomen, unnamed but widely understood, among others, Black native-born Congresswoman Ayanna S. Pressley, to "go back" to their home countries). Cf. SINGH, supra note 76, at 21-22 (noting history of treating Black Americans, along with immigrants and other subordinated groups, as the excluded other against which American identity is defined).

227 Jan Ransom, Trump Will Not Apologize for Calling for Death Penalty over Central Park Five, N.Y. Times (June 18, 2019) https://www.nytimes.com/2019/06/18/nyregion/central-park-fivetrump.html [https://perma.cc/43YT-4KPD].

228 Shelby Cty. v. Holder, 133 S. Ct. 2612, 2631 (2013). 
the state, as in how that law reflects our reconception of ourselves as a people who have participated in our own and our nation's transformation. ${ }^{229}$

In other words, the activity of Constitutional rebuilding, however incompletely achieved, is the point, for it is that rebuilding process that builds the people. I choose to aggressively read Lawrence and the ambiguity of the "ourselves" and "a people" in his last sentence to suppose both that it builds long-run capacity in Black Americans to exercise authorship, and that it builds the composite American demos up to be closer to the kind of demos that can genuinely exercise popular authorship.

Ralph Ellison provided an evocative description of this process of imaginative democracy-rebuilding in a review of Howard Zinn's The Southern Mystique:

Negroes also know ... that you prepare yourself for desegregation and the opportunities to be released thereby before that freedom actually exists. Indeed, it is in the process of preparation for an elected role that the techniques of freedom are discovered and that freedom itself is released.

The Negro Freedom Party of Mississippi, for instance, arose out of a mock political action, and as a mockery of the fraudulent democracy of the Democratic party of Mississippi. Its mockery took the form of developing techniques for teaching Negroes denied the right to vote how to form a political party and participate in the elective process. In the beginning it possessed all of the "artificiality" of a ritual, but the events, the "drama" acted out in Atlantic City, saw the transformation of their mockery and play-acting into a significant political gesture that plunged them into the realms of conscious history. Here the old slave proverb "Change the joke and slip the yoke" proved a lasting bit of wisdom. For Negroes, the Supreme Court Decision of 1954 and the Civil Rights Act of 1964 induced no sudden transformation of character; it provided the stage upon which they could reveal themselves for what their experiences have made them and for what they have made of their experiences. Here the past and the present come together, making possible a collaboration, across the years, between the old abolitionists and such contemporary activists as Howard Zinn. Nor should we forget that today Negroes are freeing themselves. ${ }^{230}$

That passage really sums up the whole thing — cynical faith, the process of actively building democracy through struggle, where the struggle itself comes to constitute the democracy, and the way in which this struggle and learning fills out the intergenerational conversation imagined by constitutional conception theorists such as Professors Ackerman and Habermas. Even mockery - whether mockery of the Jim Crow Democratic

229 Charles R. Lawrence III, The Fire This Time: Black Lives Matter, Abolitionist Pedagogy and the Law, 65 J. LEGAL EDUC. 381, 387 (2015).

230 RALPH ELLISON, GOING TO THE TERRITORY 102-03 (1986). 
Party or the mockery that the original Constitution claims to speak for "We the People" - can come to life through an intergenerational process of experience and activism. And it even expresses the sense of destiny that has run through so much of Black constitutional thought - from Ellison's reference to "an elected role," clearly referring to the idea of a people chosen for that role by providence, not by the voters, to James McCune Smith's vision of Black Americans as the destined saviors of American constitutional democracy.

Thus, the line of thought spanning Douglass, and Lawrence, and Ellison, counsels activists for freedom and equality - for inclusion - to keep going. It counsels activists to recognize the victories that have been won, and the way that these victories - though they do not amount to full inclusionnonetheless have further built the normative foundation of the Constitution. The Habermasian learning process has begun, albeit how Douglass expected it to begin-agonistically, with action and conflict-rather than the rationalistic discursive process Professor Habermas likes to imagine. And though the learning is far from complete, the result of what the nascent demos has learned so far, in the course of its struggle to come into being, has been a progressive strengthening of the kinds of moral claims that America's constitution warrants and permits to be converted into legal claims. No matter what the Supreme Court does in the next few years, no matter how many civil rights it manages to strike down, so long as America's constitutional text and history are remembered, lawyers and activists will always be able to point to the clearer articulation of the principles of freedom and equality that Black soldiers helped write into the Constitution, and, to the history of antidiscrimination law and affirmative inclusion that Black activists helped write into its interpretative principles - even if only for a time. And in the next round, those claims will still be stronger-Douglass's "abolition statesmen" will have more to work with.

The Douglass line of thought ultimately becomes an expansion of the constitutional conception. Even though there isn't a genuine We the People, those of us who would build it up have good reason to create a constitutional culture - to press the state to adhere to the promises latent in the Constitution, to build and support individual and collective commitments to its values - in order that this culture may educate those who are not currently faithful to its values (although they may believe they are). Rather than Habermasian discourse, this Constitution, the Constitution that is and is yet to be, reveals itself to all of its nascent people through struggles over its realization. And if it is finally realized - or at least as it makes halting steps toward realization, the Douglass line of thought grants it retroactive validity 
by recognizing that the demos built by this realization really was already there - albeit latently - to validate it all along.

From another direction, Black constitutional patriotism can be seen as a recipe for reconciliation. Reconciliation is a term of art in political philosophy in a tradition running roughly through Hegel and Rawls, and represents a goal of that tradition: to help people see the virtues of their political orders rather than be alienated from them; to allow them to have a sense of genuine belonging in their societies. ${ }^{231}$ I submit that the task of reconciliation is particularly urgent in democratic constitutional theory, for while people who see their societies as merely unjust might seek to use democratic processes to change them, those who see their societies as undemocratic may perceive themselves as lacking nonviolent options.

Nonetheless, as Rawls recognized, there is a danger that reconciliationdriven political theory may become "ideological in Marx's sense"-in other words, it may be "used corruptly as a defense of an unjust and unworthy status quo. ${ }^{2} 32$ Fortunately, Douglass and his intellectual heirs show a path to reconciliation without ideology. The injustice of the status quo can be recognized, but the claims to rightness issued by the defenders of the status quo can nonetheless be used as a moral resource to bring the community to a place where genuine reconciliation is possible.

Hegel captured the idea of reconciliation through the metaphor of being "at home" in one's society. ${ }^{233}$ That metaphor resonates far too well with the history of Black activism to not extend it here. American writer and poet Audre Lorde once said that "the master's tools will never dismantle the master's house." ${ }^{234}$ Well, maybe they won't—but Douglass asks us to use those tools to renovate it into a space that can accommodate those who had been the slaves. Builders and realtors will say that an uninhabitable house on a solid foundation has "good bones"; Douglass and his intellectual heirs have seen that our Constitution has good bones too, even it takes a truly heroic amount of work to bring those bones out.

For those reasons, Black constitutional patriotism gives Americans of all races genuine reason to adhere to the Constitution in potentia. And they give constitutional and democratic theorists of all countries an intellectual warrant to accept a version of the constitutional conception of popular

231 See generally John Rawls, Justice As FAIRnESS: A RestatemENT 3-4 (Erin Kelly ed., 2001); Michael O. Hardimon, The Project of Reconciliation: Hegel's Social Philosophy, 21 PHIL. \& PUB. AfF. 165,165 (1992).

${ }^{232}$ RAWLS, supra note 231, at 4 n.4.

233 Hardimon, supra note 231, at 168.

234 Audre Lorde, The Master's Tools Will NeVer DismantLe the Master's House (1983), reprinted in FEMINIST POSTCOLONIAL THeORY: A READER 25, 25 (Reina Lewis \& Sara Mills eds., 2003). 
sovereignty that recognizes that in deeply unjust aspirant democracies, the capacity for popular authorship must be built in struggle and faith, not merely exercised in the discursive politics of the already-included. 
N O R T H W ESTER N U N IVER S T Y LA W R E VIE W 